\title{
Intra-Industry Trade and Determinants: Evidence for ASEAN-Australia and New Zealand in the Context of AANZFTA
}

\author{
Sayeeda Bano \\ The University of Waikato, Hamilton, New Zealand \\ Tel: 64-7-838-4931Ｅ-mail: sbano@waikato.ac.nz
}

Received: September 7, 2018 Accepted: October 11, 2018 Published: October 14, 2018

doi:10.5296/ijafr.v8i4.13778

URL: https://doi.org/10.5296/ijafr.v8i4.13778

\begin{abstract}
This study examines the changing patterns and direction of trade between Association of South- East Asian Nations (ASEAN), Australia and New Zealand in the context of the ASEAN-Australia-New Zealand Free Trade Area/Agreement (AANZFTA) signed in 2010. It investigates the extent of ASEAN's intra-industry trade with Australia and New Zealand at the 3-digit disaggregated SITC level for the period 1990 to 2014. The study includes an analysis of intra-industry trade indices of trade intensities, the marginal intra-industry trade and the econometric model to identify the determinants of intra-industry trade. The results show that trade in general has increased and intra-industry trade between ASEAN-Australia increased specifically in manufacturing. New Zealand has developed intra-industry trade in both the manufacturing and agriculture sectors. Marginal intra- industry results suggest that some industries transforming from inter-industry trade patterns to intra-industry trade. The results of regression analysis provide some support to the thesis that increase in IIT comes naturally with high average incomes of trade partners and large average market size. As a country's level of income goes up and its standard of living rise, its citizens tend demand and consume more high quality differentiated products, leading to higher levels of intra-industry trade. This study differs from the existing literature in terms of its scope, methods and policy perspectives. The findings have policy relevance for the ongoing negotiations for a regional comprehensive economic partnership with ASEAN 10, India, China, Japan, Australia and New Zealand. It is reasonable to suggest that intra-industry trade be given due consideration in ongoing regional and bilateral trade negotiations for potential mutual gains from trade for a sustainable regional economic growth.
\end{abstract}

Keywords: Economic integration, ASEAN, Australia, New Zealand, AANZFTA, CER, FTAs JEL: F10, F02, F13, F14, F15 


\section{Introduction}

The Association of Southeast Asian Nations (ASEAN) was established in Bangkok in 8 August 1967 by Indonesia, Malaysia, Philippines, Singapore, and Thailand. Brunei Darussalam in 1984, Vietnam in 1995, Laos and Myanmar in 1997 and Cambodia later joined the founding members in April 1999. ASEAN's stated aim was to accelerate economic growth, social progress and cultural development in the region; advance regional peace and stability as well as respect for justice and the rule of law; and promote adherence to the principles of the United Nations Charter in the region.

Since the 1970s, ASEAN has been one of the fastest growing regions of the world, following on the heels of the East Asian tigers (Singapore, South Korea, Taiwan and Hong Kong). Although their growth momentum was interrupted by the Asian financial crisis of 1997-1998, it resumed soon afterwards. A large part of the rapid growth in the region is widely attributed to international trade.

Geographically close by to ASEAN are the two developed countries of Australia and New Zealand, which have historically maintained close economic ties with each other. In 1983, Australia and New Zealand took a step further in their relationship and signed the Closer Economic Relations (CER), whose aim is to facilitate trade and investment linkages between them.

In 1995, formal consultations started between the Economic Ministers of ASEAN and the CER with the aim of improving two-way trade and investment between the two regions. In September 1996, the Ministers signed an MOU to promote cooperation on standards and conformance and engage in other areas of joint activity, such as customs facilitation, information exchange and human resources development. Finally, in 2010, ASEAN and the two CER countries signed the ASEAN-Australia-New Zealand Free Trade Agreement (AANZFTA), which aims to further boost trade and economic relations in the region. Since it has been eight years since the signing of AANZFTA, it is the right time to assess if the Agreement has achieved some of its objectives.

\subsection{Objectives}

This paper aims to analyse the changing patterns of trade in the context of ASEAN-AustraliaNew Zealand free trade agreement (AANZFTA) signed in 2010. In addition, the study aims to contribute to the empirical literature on intra-industry trade at disaggregated industry level, and to marginal/dynamic intra-industry trade for dynamic analysis. It is expected that the findings will be useful to policy makers in their task of enhancing and shaping trade so that its contribution to growth and sustainable development is maximized. ASEAN is important for New Zealand and Australia and Australia, New Zealand are also important trade partners for ASEAN. AANZFTA is an important case study, where two regions jointly signed an FTA,

This study has eight major parts or sections. The first section, which includes 1 and 2, serves as the introduction. The third section presents literature review relevant to this study. The fourth section presents data sources, methodology and hypotheses. In section five presents, bilateral trade with ASEAN-Australia, as well as ASEAN and New Zealand during the period 
from 1990 to 2014. This is followed, by an examination of the intensity or extent of intraindustry trade, and its determinants. The results of the examination are then analysed and interpreted. The final section presents the conclusions and the some suggestions for further research.

\section{Review of Relevant Literature}

The emergence of intra-industry trade (IIT) has attracted increasing attention from economists, businesses and policy makers since 1960s. With the growth of IIT, traditional trade theories, which dominated earlier periods like the Heckscher-Ohlin explanation of inter-industry trade patterns and the nineteenth century Ricardian model of exchange - in which British cloth is exchanged for Portuguese wine - were called into question. Wine and cloth, of course, belong to different industries; hence, the exchange is inter-industry, or the exchange of products belonging to different industries. Intra-industry is defined as the simultaneous exports and imports within the same industry.

Among the first to investigate the presence of IIT among advanced countries was Kojima (1964), who divided the subject countries into three groups according to the types of products that they produced and traded. His study showed that the most advanced countries, such as the US, UK and the EEC, had intense intra-industry trade in almost all commodity categories. Japan and Canada, not being as advanced (at that time) as the first group, had partial intra-industry trade, while the third group, consisting of Australia and New Zealand which produced and traded more primary products, had inter-industry trade. Kojima suggested, along Linder's demand similarity thesis, comparative costs or economies of scale as a possible explanation for the results. Krugman (1979), who argued that economies of scale are an important driver of IIT due to imperfect competition in the relevant markets, later supported Kojima's findings.

In a study of the trade patterns among the EEC countries, Balassa (1966) concluded that trade between industrial countries is intra-industry rather than inter-industry (and hence was not harmful to US exports). Greenaway, Hine and Milner (1994) analyzed horizontal and vertical IIT of the UK in 1988. They disentangled two kinds of IITs by unit value index; using this approach, they tested the relationships between industry-specific factors and IIT. Their findings were that vertical IIT was more important than horizontal IIT in 1988, and that scale economies, product differentiation and imperfect competition were determinants of IIT. The authors emphasized that the empirical results would have been seriously impaired by a failure to separate vertical and horizontal IIT. In another paper, Greenaway, Hine and Milner (1994) used the same methods and data set to analyze country-specific factors in the UK's vertical and horizontal IIT. Their results showed that market size and membership in a customs union, but not factor endowments, are related to the UK's vertical IIT.

Using an approach similar to Greenaway, Hine and Milner but differing in the choice of parameters, Fontagné, Freudenberg and Gaulier (2006) obtained horizontal and vertical IITs for all countries in the world. Their findings showed that while vertical IIT between European countries increased, inter-industry trade moved in the opposite direction. 


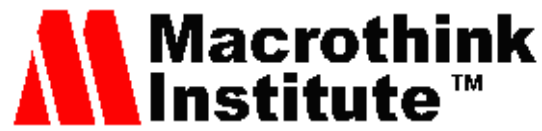

International Journal of Accounting and Financial Reporting

ISSN 2162-3082

2018, Vol. 8, No. 4

Azhar and Elliott (2006) argued that the unit value approaches of Greenaway et al. and Fontagne at al. had a "disproportionate scaling issue" that may cause measurement problems and proposed instead a geometric tool that can provide a simple and more versatile method. Sawyer et al (2010) examined the level of IIT of 22 countries in East, Southeast, South, and Central Asia in 2003. IIT is measured as a multilateral trade-weighted index and is reported for ten different categories of goods in the primary and secondary sectors. A Tobit regression model is used to investigate the determinants of IIT. Their results showed that ASEAN and the high-income countries in East Asia exhibit the highest levels of IIT, followed closely by China and India. R\&D spending, openness, and a higher share of manufactured exports were found to promote IIT, while geographical distance and difference in economic size among the countries had a negative effect, especially for manufactured goods.

$\mathrm{He}$ and Yu (2013) empirically analyzed the factors that impact the agricultural IIT between Guangxi Province (China) and ASEAN during the period 2001-2011. Per capita GDP, foreign direct investment, the labor-capital ratio and economic integration were found to contribute significantly to the development of regional IIT in agricultural products. But difference in per capita GDP between Guangxi Province and ASEAN is a major reason for the sluggish development of IIT.

Jambor (2014) identified the determinants of horizontal and vertical IIT in agriculture and food during the period 1999-2010 between the New Member States (NMS) and the original members of the EU; the results showed that economic integration (i.e., joining the EU) fostered IIT between the two groups of members.

Using panel data in the period 1997-2011, Phan and Jeong (2014) showed that the IIT of Korean and ASEAN manufacturing is positively correlated with average income levels and foreign direct investment inflows and negatively correlated with the differences in factor endowments. Overall, market size, income dissimilarity and factor endowments appear to be the most important determinants of IIT in manufacturing between Korea and ASEAN.

In a 2014 paper, Varma and Ramakrishnan used econometric analysis to study the structure and determinants of trade in agricultural and food products between India and members of selected free trade agreements (FTA). Their analysis showed that FTA had a positive impact on IIT and that relative IIT is higher for members of SAFTA (South Asia Free Trade Association) such as Bhutan, Bangladesh and Nepal of SAFTA and Singapore of the ASEAN. Similarities in demand and related factor endowments were also shown to have a positive impact on IIT. But greater dissimilarities in GDP and GDP per capita are associated with higher IIT.

Lapiňska (2015) investigated the determinants of IIT between Poland and its EU trading partners. The author found out that economic integration with the EU tended to be a positive factor influencing the development of IIT, while trade barriers and the degree of trade imbalance between Poland and its partners negatively affected its development. On the other hand, Soo (2016) used UN Comtrade database and developed a model of international trade. The developed model predicted the trade-weighted Grubel-Lloyd index of intra-industry. The researcher found that intra-industry trade is positively associated with the number of exported 
sectors, and negatively associated with the number of imported sectors. However, the model was not better fit for the OECD (Note 1) countries.

Wagner (2017) used transaction level data of all exports and imports about the intra-good trade in the context of Germany. The researcher segregated the firms into two groups a) the firms who export and import different goods (inter-good) and b) the firms who export and import identical goods (intra-good). Interestingly, findings revealed that intra-good trade contributes to the total trade more than the inter-good trade. Perhaps due to better research and development, high degree of productivity, and more human capital intensity. However, the researcher did not explore why some firms engage in intra-good trade. The author suggests the significant role intra-goods trade (the simultaneous export and import of identical goods by one firm) is likely to play in fostering new trade pattern. The Author suggests that future research focus may consider exploring further to investigate the role intra-goods (intra-firm) trade in international trade using data from across different countries and regions. This study attempts to fill the significant research gaps.

\section{Data and Methodology}

\subsection{Data Sources}

Data on trade between countries are measured in US dollars and are obtained from the UN COMTRADE Database, the United Nations Commodity trade website and the UNCTAD Database. The determinants of Intra-industry Trade; ALDjk, AMSjk, LDDjk and MSDjk, are calculated by the author from raw data from the World Bank's World Development Indicators. The total trade for ASEAN includes data from seven member-countries: Brunei Darussalam, Indonesia, Malaysia, Philippines, Singapore, Thailand and Vietnam.

Time series data for the period 1990-2014 are used to estimate the share of ASEAN's IIT with Australia and New Zealand. To make the analysis dynamic, marginal intra-industry trade is used. For the empirical tests, we use hypotheses derived from trade theories, such as Linder's demand similarity, economies of scale, product differentiation and product life cycle. Econometric analysis is used to test the hypothesized determinants of IIT between ASEAN, Australia and New Zealand.

\subsection{Methodology}

A number of attempts have been made to find a suitable method for measuring IIT and these have been discussed at length in the literature. Grubel and Lloyd (1975) measured IIT as the proportion (percent) of a country's total trade (exports plus imports) in the products of a given industry which is matched or balanced, that is, exports equal imports. In this study, four measures have been selected: (i) the Grubel and Lloyd measure at the industry level (IITBi), (ii) the Grubel-Lloyd Weighted (IITB) Index, (iii) the Grubel-Lloyd adjusted (IITC) Index, and (iv) the Aquino adjusted index. In order to address the dynamic aspects, this study considers the marginal intra-industry trade methods. Summaries of the methodologies used are presented in Appendix 1.

Hamilton and Kniest (1991) argued that although static indices of IIT, like the widely- used 


\section{MInstitute ${ }^{\text {Mink }}$}

International Journal of Accounting and Financial Reporting

ISSN 2162-3082

Grubel-Lloyd index, are informative and most widely used, dynamic indices may be more useful. Alternative dynamic indices have therefore been developed. Brülhart (2002) introduced the development of MIIT indices in detail. The first measure is the Hamilton-Kniest (HK) Index, which captures the structural change in IIT through the ratio of first differences in exports and imports. However, it is undefined when either exports or imports decrease.

The Hamilton- Kniest MIIT index is:

$$
\mathrm{HK}=\left\{\begin{array}{cl}
\frac{\Delta X}{\Delta M} & \text { for } \Delta M>\Delta X \geq 0 \\
\frac{\Delta M}{\Delta X} & \text { for } \Delta X>\Delta M \geq 0 \\
1 & \text { for } \Delta X=\Delta M>0 \\
\text { undefined } & \text { for } \Delta X<0 \text { or } \Delta M<0
\end{array}\right.
$$

Brülhart (1994) proposed a Grubel-Lloyd style MIIT index as follows:

$$
B^{A}=1-\frac{|\Delta X-\Delta M|}{|\Delta X|+|\Delta M|}
$$

Where,

$\mathrm{X}$ is exports

$\mathrm{M}$ is imports

HK is Hamilton and Kniest index, and

BA is the Brülhart index.

The Brulhart index is similar to the Grubel-Lloyd index in that the index is zero when marginal trade in the industry is completely inter-industry and unity when it is total intra-industry. Also like the Grubel-Lloyd index, the Brulhart index can be aggregated for all industries. Other MIIT indices have also been proposed, such as the Thom and McDowell (1999) index and the Annicchiarico and Quintieri (2000) index. As Brülhart (2002) has pointed out, different indices capture different aspects of the structure of trade changes, but no one measure is able to fully capture trade.

The widely accepted Chamberlin-Heckscher-Ohlin (C-H-O) model provides explanations of both inter-industry and intra-industry trade. Under $\mathrm{C}-\mathrm{H}-\mathrm{O}$, inter-industry trade specializes in homogeneous goods while intra-industry trade specializes in horizontally differentiated goods. Greenaway and Milner (2002), however, argue that this view is misplaced, citing evidence that the $\mathrm{C}-\mathrm{H}-\mathrm{O}$ model wrongly measured horizontal IIT as total IIT, forgetting that vertical IIT is also an important part of international trade. According to Greenaway et al, horizontal IIT is based on the need for variety of goods and economies of scale, while vertical IIT is based on the preference for variety which results from income differences. 


\section{MlMacrothink}

International Journal of Accounting and Financial Reporting

ISSN 2162-3082

2018, Vol. 8, No. 4

\subsection{Determinants of IIT}

Selected hypotheses derived from Linder's demand similarity theory:

Hypothesis 1: IIT is an increasing function of the average level of development $\left(A L D_{j k}\right)$ of the trading partners, measured as the average per capita income of the two countries, $j$, home /reporting country and $k$, trading partner.

$$
\delta I I T_{j k} / \delta A L D_{j k}>0
$$

Hypothesis 2: IIT is an increasing function of the average market size $\left(A M S_{j k}\right)$ of the trade partners, measured by average GDP.

$$
\delta I I T_{j k} / \delta A M S_{j k}>0
$$

Hypothesis 3: IIT is a decreasing function of the level of development differential $\left(L D D_{j k}\right)$ - i.e. absolute difference of the per capita incomes of the trading partners.

$$
\delta I I T_{j k} / \delta L D D_{j k}<0
$$

Hypothesis 4: IIT is a decreasing function of the level of (development differential) market size differences $\left(M S D_{j k}\right)$ - i.e. absolute difference of the GDPs of the trading partners.

$$
\delta I I T_{j k} / \delta M S D_{j k}<0
$$

\section{Overview of Bilateral Trade Between the Partners}

\subsection{ASEAN Trade With Australia}

Figure 1a below shows that ASEAN trade with Australia has increased significantly over time, with exports from ASEAN to Australia increasing faster than imports, especially during 1990-2014. During the same period, the shares of ASEAN exports to Australia and imports from the latter moved in opposite directions [See Figure 1b]. In 1990-1998, the share of ASEAN exports was less than the share of imports in ASEAN's total trade, but became greater subsequently. Overall, the share of ASEAN exports to Australia increased significantly, especially prior to 2009. By contrast, since 1990 the share of ASEAN imports from Australia has decreased gradually, although in 2013-2014 the share of ASEAN trade (both imports and exports) with Australia in ASEAN total trade remained relatively constant.

Overall, the shares of SITC 3 (Mineral Fuels) and 7 (Machinery \& Transport equipment) between ASEAN and Australia have been dominant in ASEAN's total trade with Australia [See Figure 1c]. These two sectors together accounted for more than half of their bilateral trade. However, the trends in the two shares moved in opposite directions during the period, with ASEAN trade with Australia in SITC 3 increasing significantly from 11 percent in 1995 to around 33 percent in 2014, and trade in SITC 7 decreasing gradually from 25 percent to around 21 percent in 2014. The shares of other commodities in the total trade have remained relatively constant. 


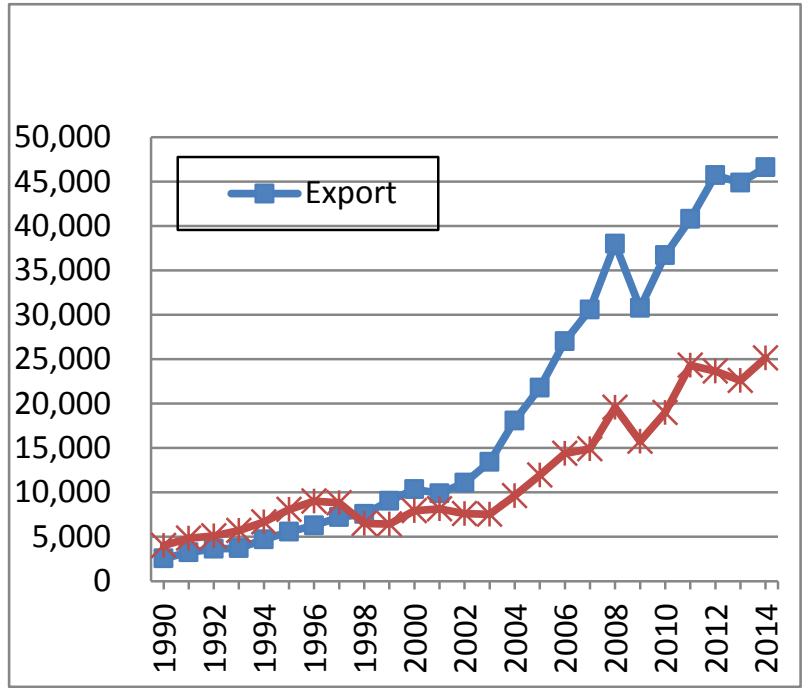

Figure 1a. ASEAN trade with Australia over time: 1990-2014 (in US\$ Millions)

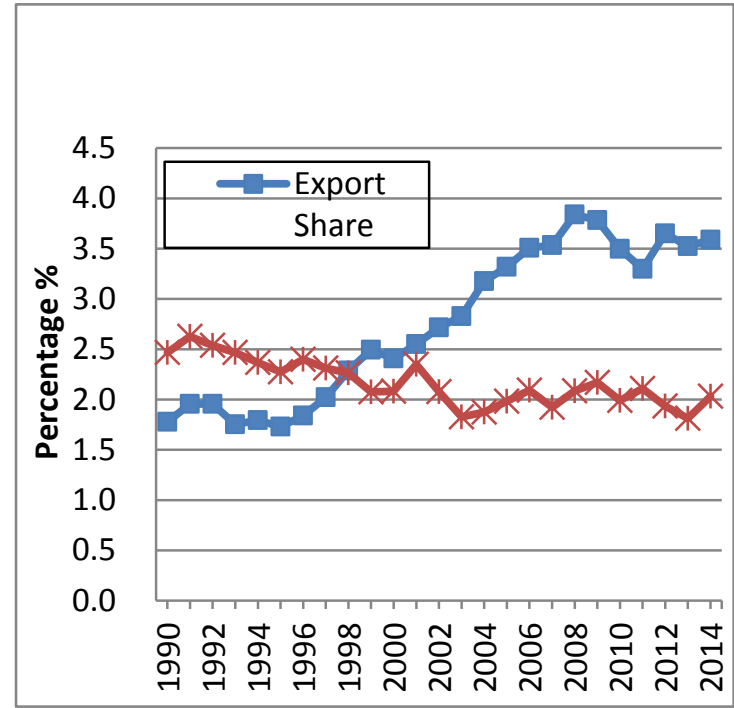

Figure 1b. Share of ASEAN-AUS trades in ASEAN total trades: 1990-2014

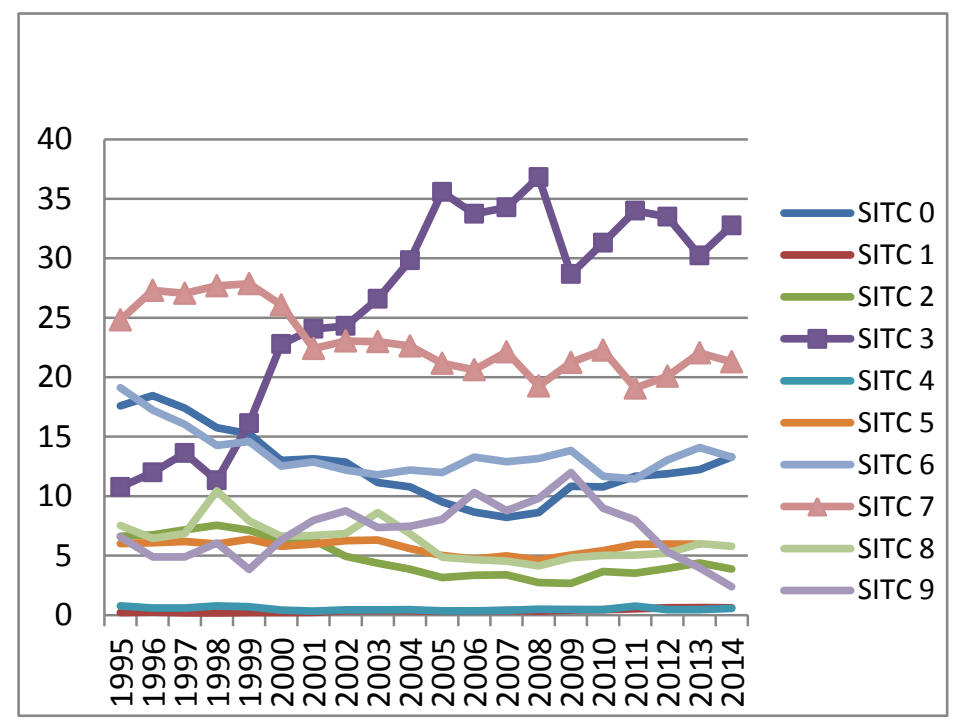

Figure 1c. Share of Australia in ASEAN-Australia total trade by sectors: 1995-2014

Figure 1. ASEAN's total trade with Australia

Source: UNCTAD Database, 2015, Author's calculation.

\subsection{ASEAN Trade With New Zealand}

Figure 2a shows that both imports and exports between ASEAN and New Zealand increased significantly, with only slight fluctuations. During 1990-1999, ASEAN imports from New Zealand were greater than its exports. Since 2002, however, ASEAN exports to New Zealand have been much higher than its imports.

For 1990-2002, the share of ASEAN-New Zealand imports in ASEAN's total trade was greater than the share of exports. For 2003-2014, the share of ASEAN-New Zealand exports 


\section{Mll Macrothink}

International Journal of Accounting and Financial Reporting ISSN 2162-3082

increased much faster than the share of imports. Overall, there has been an increasing trend in the share of ASEAN exports to New Zealand. On the other hand, the share of ASEAN imports from New Zealand has remained relatively constant. In recent years, the shares of ASEAN and New Zealand exports and imports moved in opposite directions [see Figure 2b].

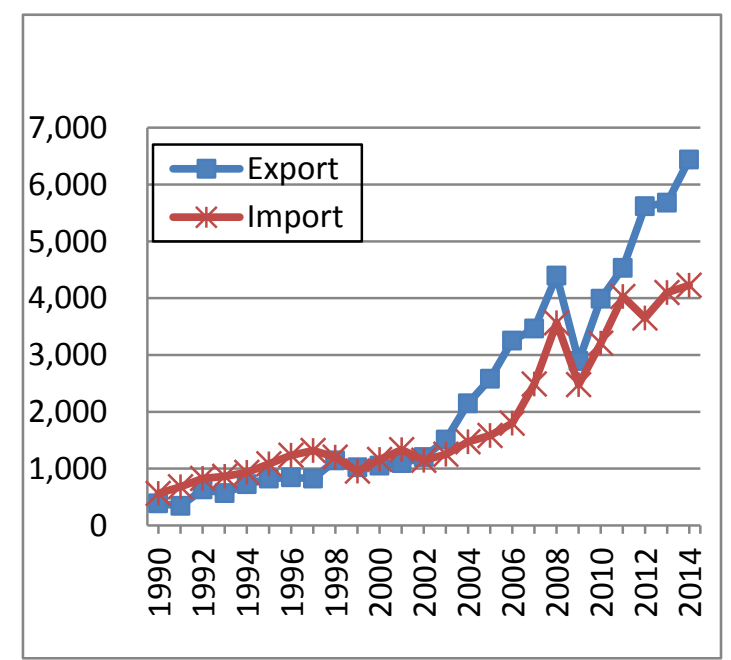

Figure 2a. ASEAN-NZ trade over time: 1990-2014 (in US\$ Millions)

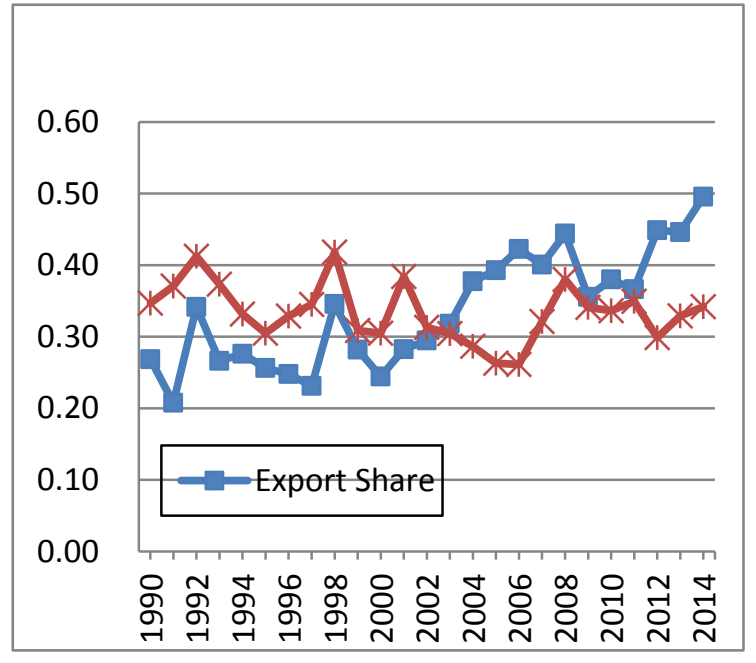

Figure 2b. Share of ASEAN-NZ trades in ASEAN total trades: 1990-2014

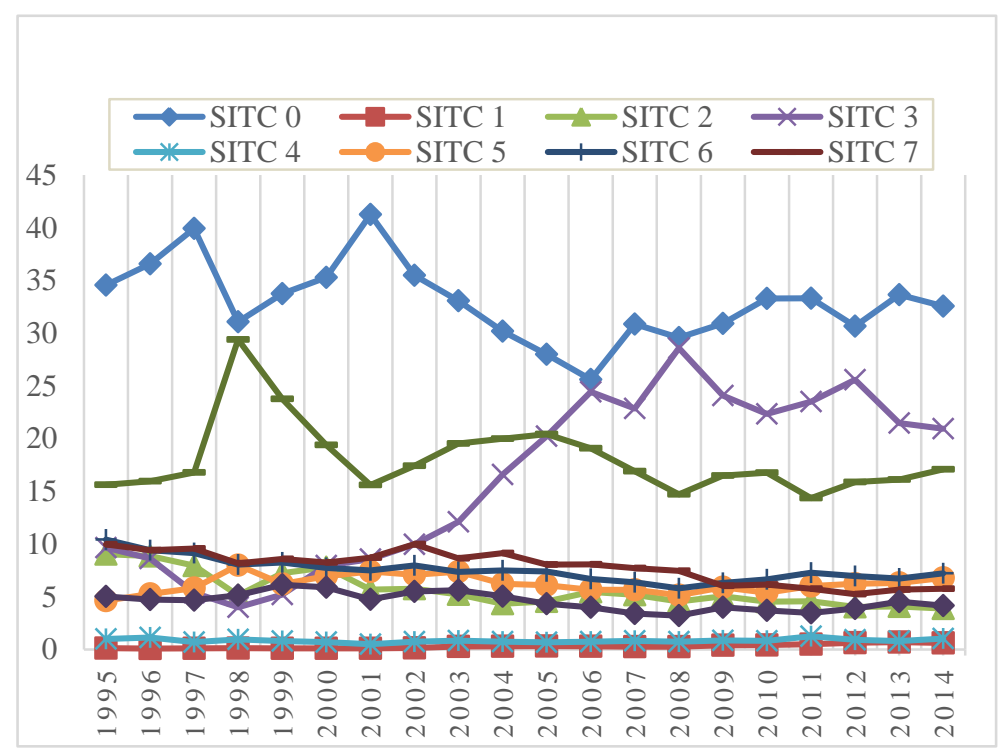

Figure 2c. Share of NZ in ASEAN-NZ total trade by sectors

Figure 2. The shares of ASEAN and New Zealand exports and imports

Source: UNCTAD Database, 2015, Author's calculation.

Similarly, ASEAN trade with New Zealand in SITC 0 (Food and Live Animals), 3 (Mineral Fuels) and 8 (Miscellaneous Manufactured Articles) together contributed to more than half of the share in ASEAN's total trade with NZ. Although fluctuating, trade in SITC 3 significantly improved over the period, while trade in SITC 0 and 8 remained constant. ASEAN trade with $\mathrm{NZ}$ in other sectors remained relatively constant. [See Figure 2c] 


\section{Macrothink}

International Journal of Accounting and Financial Reporting ISSN 2162-3082 2018, Vol. 8, No. 4

\subsection{Australia's Trade With ASEAN}

Since 1998, Australia has had a trade deficit with ASEAN [See Figure 3a], and since 2000, the shares of Australia-ASEAN exports and imports in Australia's total trade have moved in opposite directions. But overall the share of Australia's exports to ASEAN was greater than the share of Australia's imports from ASEAN before 1998, the year of the Asian financial crisis [See Figure 3b]. Subsequently, the share of exports in Australia's total trade decreased gradually from 14 percent to no more than 10 percent in 2000-2013. By contrast, the share of Australia's imports from ASEAN increased steadily before 2008, but decreased from 20 percent to a constant 17 percent in recent years. In 2014, the share of exports increased slightly to 11 percent.

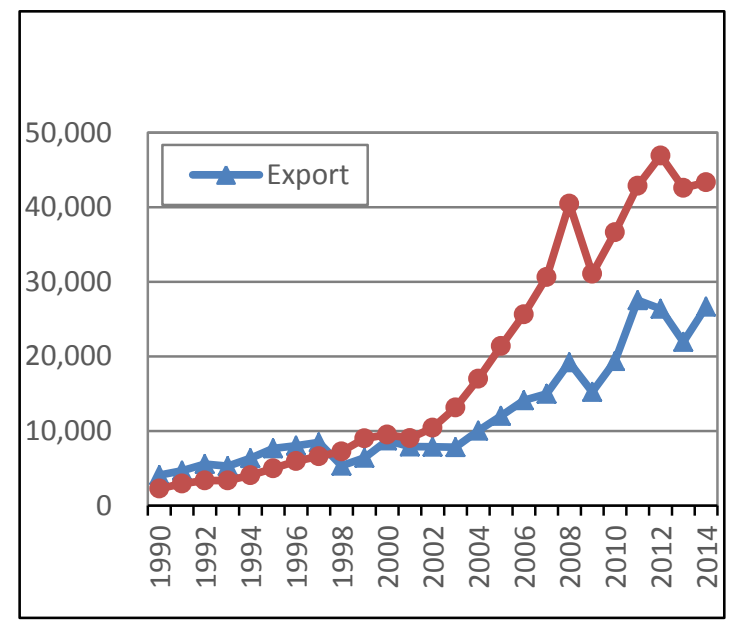

Figure 3a. Australia's trade with ASEAN: 1990-2014 (in US\$ Millions)

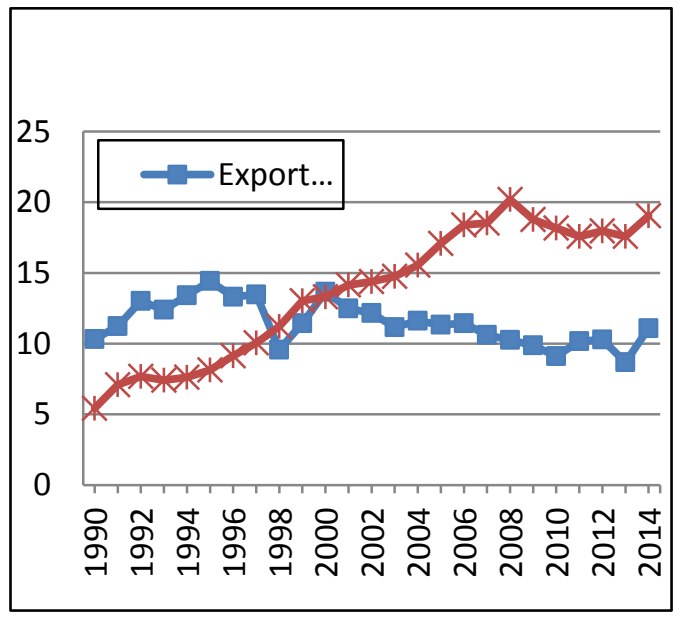

Figure 3b. Share of AUS-ASEAN trades in AUS total trades: 1990-2014

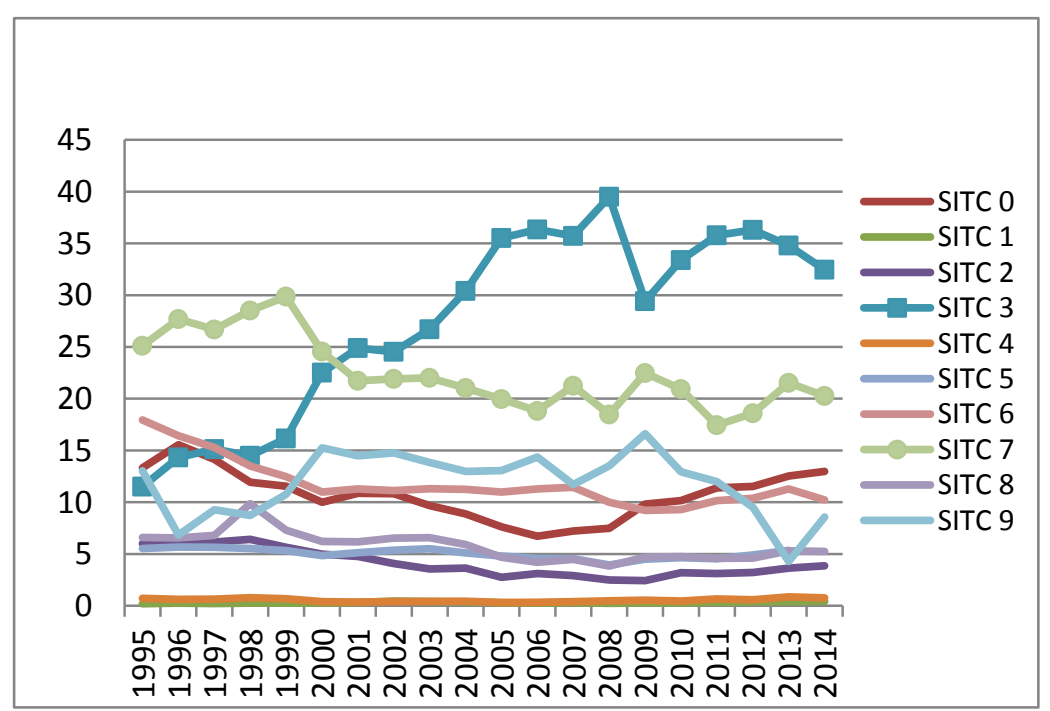

Figure 3c. Share of AUS by sectors in ASEAN-AUS total trade: 1995-2014

Figure 3. The share of Australia's exports to ASEAN

Source: UNCTAD Database,2015, Author's calculation. 


\section{MIMacrothink}

International Journal of Accounting and Financial Reporting ISSN 2162-3082 2018, Vol. 8, No. 4

SITC 3 (Mineral fuels) and 7 (Machinery \& Transport equipment) dominated Australia's trade with ASEAN, but the share of SITC 7 declined while that of SITC 3 increased during the period. Australia's trade with ASEAN in SITC 9 (Commodities and Transactions not Classified) has also been declining, which means an improvement of trade in primary sectors during the period [See Figure 3c].

\subsection{New Zealand's Trade With ASEAN}

Since 2000, New Zealand's imports have been higher than its exports to ASEAN. Moreover, New Zealand's imports have also increased much faster than its exports, suggesting an increasing trade deficit for New Zealand [See Figure 4a].

The shares of exports and imports between New Zealand and ASEAN increased gradually over 1990-2001, with New Zealand exports to ASEAN being greater than the share of New Zealand imports from ASEAN. Thereafter, the share of imports showed a significant increase from 9 percent in 2001 to more than 15 percent in 2014, making the share of imports greater than the share of exports. By contrast, the share of New Zealand exports to ASEAN in New Zealand's total trade remained relatively constant during the decade [See Figure 4b].

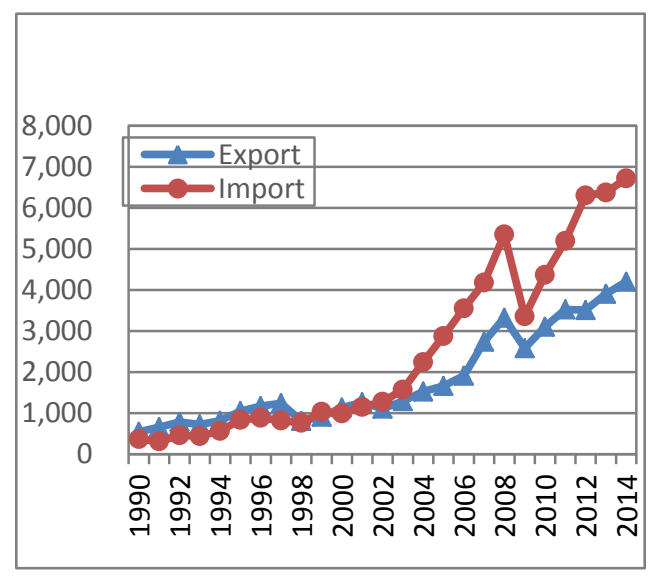

Figure 4a. NZ trade with ASEAN: 1990-2014 (in US\$ Millions)

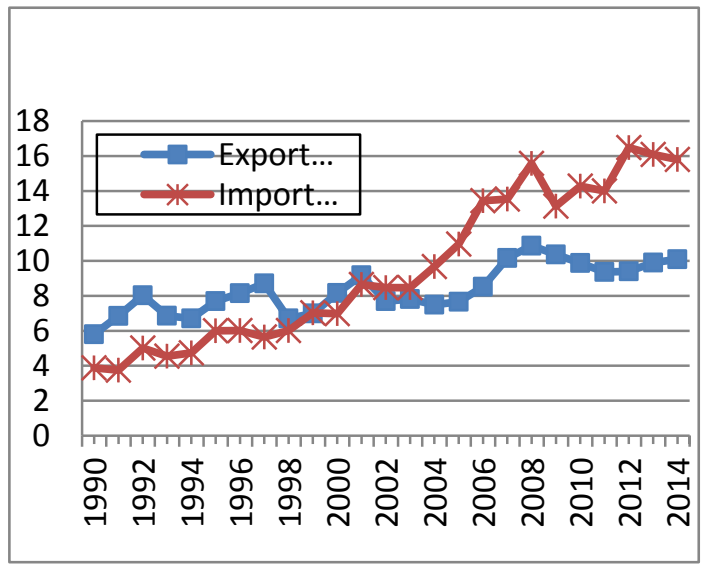

Figure $4 \mathrm{~b}$. Share of NZ-ASEAN trades in AUS total trades: 1990-2014

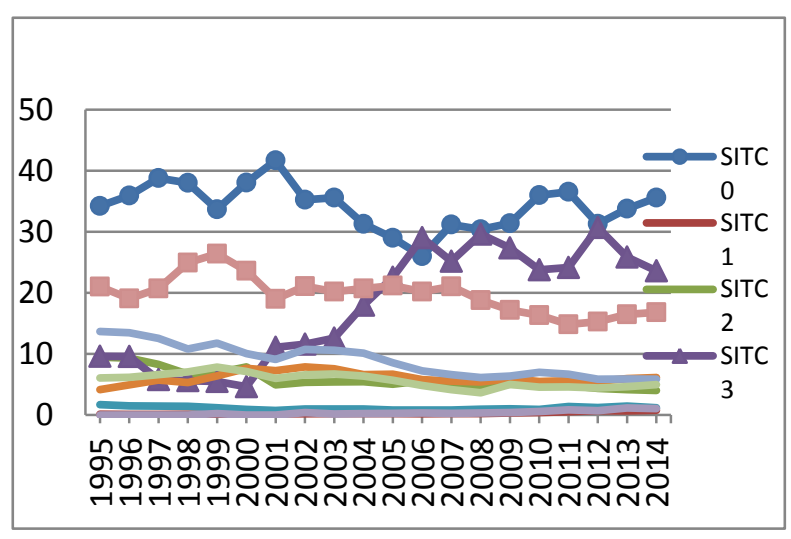

Figure 4c. Share of NZ by sectors in ASEAN-NZ total trade

Figure 4. The share of New Zealand exports to ASEAN in New Zealand's total trade Source: UNCTAD Database, 2015, Author's calculation. 


\section{MInstitute ${ }^{\text {Mink }}$}

International Journal of Accounting and Financial Reporting ISSN 2162-3082

SITC 0 (Food and live animals) and 7 (Machinery and transport equipment) dominated New Zealand's total trade with ASEAN from 1995 to 2005. SITC 3 (Mineral fuels) showed a sharp increase from an average of 5 percent in the 1990's to around 24 percent in 2014, resulting to a greater share of this sector compared to other sectors. By contrast, the share of SITC 7 decreased from 20 percent in 1995 to 17 percent in 2014, while the share of other sectors remained relatively constant, decreased only slightly over the period [See Figure 4c].

\subsection{Focus on Intra-Industry Trade}

Figure 5 shows the different measures of intra-industry trade between 1990 and 2014. From 1990 to 1996, IIT between ASEAN and Australia remained steady at an average of 42 percent, with the three measures of IIT moving in the same direction most of the time. Since then, IIT has tended to increase gradually given IITC and IITQ. However, since 1997 IIT has decreased significantly, from 40 percent to around 20 percent, using the Weighted Average measure - IITB. This suggests that trade between ASEAN and Australia tends to be interrather than intra-industry given IITB. From 2012 to 2014, IIT again decreased significantly by more than 10 percent.

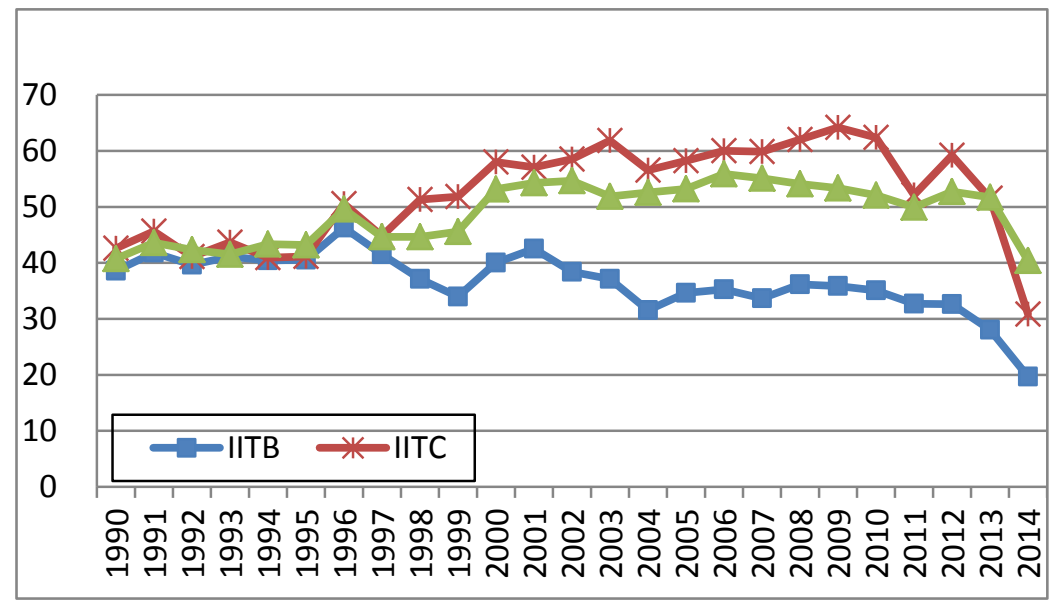

Figure 5. Intra-industry trade between 1990 and 2014 between ASEAN and Australia

Source: UNCTAD Database, 2015, Author's calculation.

\section{Results and Discussion}

\subsection{The Summary Values of ASEAN-Australia IIT by Sectors}

While intra-industry trade strengthened in Animal and Vegetable Oils (SITC 4) and Chemicals (SITC 5), it decreased or stayed constant at the other 1-digit aggregations. For example, IIT in Mineral Fuels (SITC 3) decreased from an average of around 67 percent in 1990 to 50 percent in 2014 given IITBi indices. All these suggest that trade between ASEAN and Australia tends to be inter-industry [See Tables 1a-1d].

Table B8 in Appendix B shows SITC 7 (Machinery and Transport Equipment) as having the greatest number of high IIT sectors, with nearly 100 percent levels observed in SITCs 723, 742 and 774, suggesting intra-industry trade in these sectors. On the other hand, SITC 1 (Beverage and Tobacco) and SITC 3 (Mineral Fuels) show relatively low levels of IIT, 
suggesting inter-industry trade. (The detailed IITBs for each sector are available from the author.)

Table 1a. ASEAN-Australia IIT by industry 3-digit summary values 2014 (percent)

\begin{tabular}{lllll}
\hline SITC & Description & Av-IITBi & Av-IITCi & Av-IITQi \\
\hline $\mathbf{0}$ & Food \& Live Animals & 21.26 & 59.26 & 38.04 \\
\hline $\mathbf{1}$ & Beverage \& Tobacco & 23.52 & 35.61 & 29.41 \\
\hline $\mathbf{2}$ & Crude materials inedible except fuels & 2.84 & 17.42 & 5.85 \\
\hline $\mathbf{3}$ & $\begin{array}{l}\text { Mineral Fuels Lubricants \& related } \\
\text { materials }\end{array}$ & 49.87 & 82.35 & 81.27 \\
\hline $\mathbf{4}$ & Animal \& Vegetable Oils and fats & 17.75 & 20.88 & 17.60 \\
\hline $\mathbf{5}$ & Chemicals & 20.43 & 34.74 & 23.94 \\
\hline $\mathbf{6}$ & $\begin{array}{l}\text { Manufactured Goods Classified chiefly } \\
\text { by materials }\end{array}$ & 15.23 & 20.07 & 17.80 \\
\hline $\mathbf{7}$ & Machinery \& Transport equipment & 6.46 & 86.65 & 25.12 \\
\hline $\mathbf{8}$ & Miscellaneous Manufactured Articles & 16.95 & 94.79 & 46.47 \\
\hline $\begin{array}{l}\text { Commodities } \\
\text { classified } \quad \text { Transactions }\end{array}$ & not & 19.86 & 99.24 & 99.21 \\
\hline
\end{tabular}

Table 1b. ASEAN-Australia IIT by industry 3-digit summary values 2010 (percent)

\begin{tabular}{|c|c|c|c|c|}
\hline SITC & Description & Av-IITBi & Av-IITCi & Av-IITQi \\
\hline $\mathbf{0}$ & Food \& Live Animals & 37.89 & 74.29 & 52.63 \\
\hline 1 & Beverage \& Tobacco & 78.59 & 100.00 & 93.82 \\
\hline 2 & Crude materials inedible except fuels & 5.51 & 20.97 & 8.07 \\
\hline 3 & $\begin{array}{l}\text { Mineral Fuels Lubricants \& related } \\
\text { materials }\end{array}$ & 41.51 & 88.69 & 64.84 \\
\hline
\end{tabular}




\begin{tabular}{lllll}
$\mathbf{4}$ & Animal \& Vegetable Oils and fats & 25.23 & 76.28 & 50.43 \\
\hline $\mathbf{5}$ & Chemicals & 35.51 & 49.68 & 37.65 \\
\hline $\mathbf{6}$ & $\begin{array}{l}\text { Manufactured Goods Classified chiefly by } \\
\text { materials }\end{array}$ & 24.65 & 25.19 & 24.43 \\
\hline $\mathbf{7}$ & Machinery \& Transport equipment & 20.96 & 94.19 & 43.87 \\
\hline $\mathbf{8}$ & Miscellaneous Manufactured Articles & 25.57 & 99.51 & 54.62 \\
\hline $\mathbf{9}$ & Commodities \& Transactions not classified & 77.15 & 99.94 & 93.83 \\
\hline
\end{tabular}

Table 1c. ASEAN-Australia IIT by industry 3-digit summary values 2000 (percent)

\begin{tabular}{|c|c|c|c|c|}
\hline SITC & Description & Av-IITBi & Av-IITCi & Av-IITQi \\
\hline $\mathbf{0}$ & Food \& Live Animals & 41.06 & 81.93 & 45.46 \\
\hline 1 & Beverage \& Tobacco & 25.72 & 72.61 & 43.77 \\
\hline 2 & Crude materials inedible except fuels & 10.74 & 37.53 & 11.72 \\
\hline 3 & $\begin{array}{l}\text { Mineral Fuels Lubricants \& related } \\
\text { materials }\end{array}$ & 60.50 & 96.72 & 95.02 \\
\hline 4 & Animal \& Vegetable Oils and fats & 21.65 & 61.56 & 37.73 \\
\hline 5 & Chemicals & 52.70 & 60.39 & 54.79 \\
\hline 6 & $\begin{array}{l}\text { Manufactured Goods Classified chiefly } \\
\text { by materials }\end{array}$ & 28.11 & 33.80 & 26.58 \\
\hline 7 & Machinery \& Transport equipment & 31.84 & 87.13 & 47.34 \\
\hline 8 & Miscellaneous Manufactured Articles & 38.92 & 98.94 & 54.40 \\
\hline 9 & $\begin{array}{l}\text { Commodities \& } \begin{array}{l}\text { Transactions not } \\
\text { classified }\end{array} \\
\end{array}$ & 49.03 & 57.17 & 52.14 \\
\hline
\end{tabular}


Table 1d. ASEAN-Australia IIT by industry 3-digit summary values1990 (percent)

\begin{tabular}{|c|c|c|c|c|}
\hline SITC & Description & Av-IITBi & Av-IITCi & Av-IITQi \\
\hline $\mathbf{0}$ & Food \& Live Animals & 53.02 & 68.77 & 50.86 \\
\hline 1 & Beverage \& Tobacco & 43.25 & 58.52 & 41.55 \\
\hline 2 & Crude materials inedible except fuels & 4.27 & 10.32 & 5.36 \\
\hline 3 & $\begin{array}{l}\text { Mineral Fuels Lubricants \& related } \\
\text { materials }\end{array}$ & 67.37 & 73.96 & 70.09 \\
\hline 4 & Animal \& Vegetable Oils and fats & 6.25 & 26.23 & 26.13 \\
\hline 5 & Chemicals & 0.00 & 47.49 & 41.40 \\
\hline 6 & $\begin{array}{l}\text { Manufactured Goods Classified chiefly } \\
\text { by materials }\end{array}$ & 17.44 & 30.32 & 19.24 \\
\hline 7 & Machinery \& Transport equipment & 43.73 & 57.23 & 47.06 \\
\hline 8 & Miscellaneous Manufactured Articles & 39.85 & 73.73 & 49.00 \\
\hline 9 & $\begin{array}{l}\text { Commodities \& } \begin{array}{l}\text { Transactions } \\
\text { classified }\end{array} \\
\text { not }\end{array}$ & 13.51 & 48.07 & 7.92 \\
\hline
\end{tabular}

Source: UN COMTRADE Database, 2015, Author's calculations.

\subsection{ASEAN-Australia Marginal Intra- Industry Trade (MIIT), Using the Different Indices}

Table 1e reports the results of Hamilton-Kniest (HK) MIIT index. It is observed that the marginal trade in SITC 5 (Chemicals) and 6 (Manufactured goods) is more than 50 percent over the three sub-periods. Specifically, MIIT in SITC 6 decreased from 79 percent in the first sub-period to 63 percent in the recent/third sub-period from 2011 to 2014. This means that in recent years trade in SITC 6 between ASEAN and Australia tends to be inter-industry. By comparison, MIIT in SITC 5 improved from 78 percent in the first sub-period to 91 percent in the second sub-period from 2001 to 2010, which means that exports and imports in SITC 5 changed by more or less the same amount, which is a sign of high intra-industry trade. Similarly, SITC 1 (Beverage and tobacco) is almost intra-industry during the third sub-period from 2010 to 2014. There was a reduction in the difference between the increase in exports and imports in SITC 2, 3, 4, and 8, suggesting that trade in this sector tended to be inter-industry over the period. Given a low MIIT index, the HK indexes for other sectors also show inter-industry trade patterns. 


\section{MInstitute"mk}

International Journal of Accounting and Financial Reporting ISSN 2162-3082 2018, Vol. 8, No. 4

Table 1f shows the Brülhart $(\mathrm{Ba})$ index for each sector, which is similar to what we obtained from the HK index. That is, SITC 1 and SITC 6 are almost intra-industry during some specific periods. For example, SITC 1 tends to be intra-industry trade in the third sub-period from 2011 to 2014, while SITC 6 tends to have a lower level of MIIT (78 percent) than the previous two sub-periods. In the first and second sub-periods, SITC 6 has more than 80 percent of MIIT, given by the Ba index. The high level of MIIT in those industries means that the adjustment costs or distribution effects associated with trade are supposed to be small. This is in contrast to trade in SITC 5 (not shown in the HK table), which tends to be inter-industry in recent years, although there was a high level of MIIT in the first and second sub-periods. These results provide evidence of the structural changes towards intra-industry trade between ASEAN and Australia in recent years.

Table 1e. The 10-year span Hamilton-Kniest MIIT (HK) index of ASEAN-AUS 1990-2014

\begin{tabular}{llllllllllll}
\hline HK & SITC 0 & $\mathbf{1}$ & $\mathbf{2}$ & $\mathbf{3}$ & $\mathbf{4}$ & $\mathbf{5}$ & $\mathbf{6}$ & $\mathbf{7}$ & $\mathbf{8}$ & $\mathbf{9}$ \\
\hline 1st sub-period & 0.28 & 0.06 & 0.14 & 0.31 & 0.29 & 0.78 & 0.79 & 0.15 & 0.20 & 0.19 \\
\hline 2nd sub-period & 0.45 & 0.29 & 0.19 & 0.26 & 0.17 & 0.91 & 0.74 & 0.07 & 0.10 & 0.22 \\
\hline 3rd sub-period & 0.37 & 0.98 & 0.06 & 0.22 & 0.08 & & 0.63 & 0.18 & 0.09 & \\
\hline
\end{tabular}

Table 1f. The 10-year span Brulhart MIIT (Ba) index of ASEAN-AUS; 1990-2014

\begin{tabular}{llllllllllll}
\hline Ba & SITC 0 & $\mathbf{1}$ & $\mathbf{2}$ & $\mathbf{3}$ & $\mathbf{4}$ & $\mathbf{5}$ & $\mathbf{6}$ & $\mathbf{7}$ & $\mathbf{8}$ & $\mathbf{9}$ \\
\hline 1st sub-period & 0.44 & 0.11 & 0.24 & 0.47 & 0.45 & 0.88 & 0.88 & 0.26 & 0.34 & 0.32 \\
\hline 2nd sub-period & 0.62 & 0.45 & 0.32 & 0.41 & 0.29 & 0.95 & 0.85 & 0.14 & 0.17 & 0.36 \\
\hline 3rd sub-period & 0.54 & 0.99 & 0.11 & 0.36 & 0.16 & 0.00 & 0.78 & 0.31 & 0.16 & 0.00 \\
\hline
\end{tabular}

Source: UN COMTRADE Database, 2015, Author's calculations.

Note: $1^{\text {st }}$ period refers to the 10 -year span from 1990 to $2000 ; 2^{\text {nd }}$ period refers to the 10 -year span from 2001 to 2010; $3^{\text {rd }}$ period refers to the 4-years span from 2011 to 2014.

\subsection{Intra-Industry Trade Between ASEAN and New Zealand}

Intra-industry trade strengthened in Beverage and Tobacco (SITC 1) and Mineral Fuels (SITC 3), but declined slightly or stayed constant at the other 1-digit aggregations [See Tables 2a-2d]. For instance, IIT in Food and Live Animals (SITC 0) decreased from an average of around 29 percent in 1990 to 22 percent in 2014, given IITBi indices. 
Table 2a. ASEAN-NZ IIT by industry 3-digit summary values 2014 (percent)

\begin{tabular}{lllll}
$\mathbf{S I T C}$ & Description & Av-IITBi & Av-IITCi & Av-IITQi \\
\hline $\mathbf{0}$ & Food \& Live Animals & 22.22 & 31.19 & 25.73 \\
\hline $\mathbf{1}$ & Beverage \& Tobacco & 31.52 & 58.33 & 33.58 \\
\hline $\mathbf{3}$ & Crude materials inedible except fuels & 6.40 & 91.82 & 7.72 \\
\hline $\mathbf{4}$ & Mineral Fuels Lubricants \& related materials & 19.41 & 100.00 & 97.58 \\
\hline $\mathbf{5}$ & Animal \& Vegetable Oils and fats & 2.04 & 2.26 & 2.19 \\
\hline $\mathbf{6}$ & $\begin{array}{l}\text { Chemicals } \\
\text { materials }\end{array}$ & 17.46 & 34.38 & 19.33 \\
\hline $\mathbf{7}$ & Machinery \& Transport equipment & 7.74 & 68.98 & 25.18 \\
\hline $\mathbf{8}$ & Miscellaneous Manufactured Articles & 28.18 & 94.67 & 67.46 \\
\hline $\mathbf{9}$ & \begin{tabular}{l} 
Commodities \& Transactions not classified \\
\hline
\end{tabular} & 42.85 & 94.00 & 93.60 \\
\hline
\end{tabular}

Table 2b. ASEAN-New Zealand IIT by industry 3-digit summary values 2010 (percent)

\begin{tabular}{lllll}
$\mathbf{S I T C}$ & Description & Av-IITBi & Av-IITCi & Av-IITQi \\
\hline $\mathbf{0}$ & Food \& Live Animals & 28.87 & 39.26 & 30.09 \\
\hline $\mathbf{1}$ & Beverage \& Tobacco & 75.29 & 95.59 & 76.41 \\
\hline $\mathbf{2}$ & Crude materials inedible except fuels & 6.36 & 38.22 & 29.62 \\
\hline $\mathbf{3}$ & $\begin{array}{l}\text { Mineral Fuels Lubricants \& related } \\
\text { materials }\end{array}$ & 6.74 & 99.96 & 33.17 \\
\hline $\mathbf{4}$ & Animal \& Vegetable Oils and fats & 2.72 & 12.86 & 12.43 \\
\hline $\mathbf{5}$ & Chemicals & 23.02 & 57.47 & 29.83 \\
\hline
\end{tabular}


6

Manufactured Goods Classified chiefly

by materials

$40.53 \quad 54.65$

37.67

7

Machinery \& Transport equipment

$17.66 \quad 74.39$

42.26

8

Miscellaneous Manufactured Articles

22.71

79.16

51.93

9

Commodities \& Transactions not

classified

54.97

99.00

100.00

Table 2c. ASEAN-NZ IIT by industry 3-digit summary values 2000 (percent)

\begin{tabular}{|c|c|c|c|c|}
\hline SITC & Description & Av-IITBi & Av-IITCi & Av-IITQi \\
\hline $\mathbf{0}$ & Food \& Live Animals & 21.65 & 25.76 & 23.06 \\
\hline 1 & Beverage \& Tobacco & 39.51 & 57.27 & 49.96 \\
\hline 2 & Crude materials inedible except fuels & 5.50 & 37.70 & 16.57 \\
\hline 3 & $\begin{array}{l}\text { Mineral Fuels Lubricants \& related } \\
\text { materials }\end{array}$ & 15.32 & 91.94 & 12.43 \\
\hline 4 & Animal \& Vegetable Oils and fats & 10.87 & 25.30 & 21.23 \\
\hline 5 & Chemicals & 30.52 & 37.54 & 34.41 \\
\hline 6 & $\begin{array}{l}\text { Manufactured Goods Classified chiefly } \\
\text { by materials }\end{array}$ & 34.48 & 41.88 & 32.87 \\
\hline 7 & Machinery \& Transport equipment & 20.35 & 92.16 & 46.11 \\
\hline 8 & Miscellaneous Manufactured Articles & 19.62 & 97.66 & 43.01 \\
\hline 9 & $\begin{array}{l}\text { Commodities \& } \quad \text { Transactions not } \\
\text { classified }\end{array}$ & 61.45 & 99.97 & 99.97 \\
\hline
\end{tabular}

Table 2d. ASEAN-NZ IIT by industry 3-digit summary values1990 (percent)

\begin{tabular}{lllll} 
SITC & Description & Av-IITBi & Av-IITCi & Av-IITQi \\
\hline 0 & Food \& Live Animals & 29.11 & 30.87 & 28.39 \\
\hline
\end{tabular}




\begin{tabular}{lllll}
\hline $\mathbf{1}$ & Beverage \& Tobacco & 21.96 & 69.81 & 13.90 \\
\hline $\mathbf{2}$ & Crude materials inedible except fuels & 6.31 & 23.24 & 5.04 \\
\hline $\mathbf{3}$ & $\begin{array}{l}\text { Mineral Fuels Lubricants \& related } \\
\text { materials }\end{array}$ & 0.00 & 0.00 & 0.00 \\
\hline $\mathbf{4}$ & Animal \& Vegetable Oils and fats & 7.63 & 17.20 & 16.93 \\
\hline $\mathbf{5}$ & Chemicals & 23.95 & 27.95 & 24.30 \\
\hline $\mathbf{6}$ & $\begin{array}{l}\text { Manufactured Goods Classified chiefly } \\
\text { by materials }\end{array}$ & 18.01 & 30.59 & 19.94 \\
\hline $\mathbf{7}$ & Machinery \& Transport equipment & 28.89 & 70.18 & 34.88 \\
\hline $\mathbf{8}$ & Miscellaneous Manufactured Articles & 28.08 & 77.14 & 37.55 \\
\hline $\mathbf{9}$ & $\begin{array}{l}\text { Commodities \& Transactions not } \\
\text { classified } \quad 71.73\end{array}$ & 99.98 & 99.91 \\
\hline
\end{tabular}

Source: UN COMTRADE Database, 2015, Author's calculations.

a) ASEAN IIT with New Zealand at SITC 3

Table B9 in Appendix B shows that Manufactured Goods (SITC 6) and Machinery and Transport Equipment (SITC 7) have the higher number of IIT sectors between ASEAN and New Zealand in 2014. IIT levels of more than 90 percent are observed in SITCs 273, 581, $598,635,684,694,699,772,793,871$ and 872, suggesting intra-industry trade in these sectors. On the other hand, Beverage and Tobacco (SITC 1), Mineral Fuels (SITC 3) and Animal and Vegetable Oils (SITC 4) show relatively low levels of IIT, suggesting inter-industry trade.

b) MIIT of ASEAN and New Zealand

Table 2e shows that the MIIT in all the sectors is very low, except for SITC 0 (Food and live animals) and 5 (Chemicals), which show more than 50 percent MIIT in the recent sub-period from 2011 to 2014. The difference between the increase in exports and imports in SITC 5 (Chemicals) is around 60 percent in 2010-2014, suggesting that the marginal trade in this sector tends to be intra-industry compared to other sectors. In addition, the HK indices for SITC 3 (Mineral Fuels) and 7 (Machinery and Transport Equipment) during the third sub-period are only 3 percent and 2 percent, respectively, which means that there was a substantial difference between increases in exports and imports in these two sectors from 2011 to 2014. 


\section{Macrothink}

International Journal of Accounting and Financial Reporting ISSN 2162-3082

The Brülhart indexes provide similar results, as shown in Table $2 \mathrm{f}$. For example, the marginal trade in SITC 0 (Food and Live Animals), 4 (Animal and Vegetable Oils) and 5 (Chemicals) is close to intra-industry trade in recent years, with more than 60 percent of $\mathrm{Ba}$ index. However, there are some industries, such as SITC 1 (Beverage and Tobacco), 6 (Manufactured Goods Classified chiefly by materials) and 7 (Machinery and Transport Equipment), which show diminishing levels of MIIT from the first sub-period to the latest sub-period 2011-2014. This means that exports and imports in those industries tend to change by different amounts and that adjustment costs in those sectors increased in recent years.

Table 2e. The 10-year span Hamilton-Kniest MIIT index of ASEAN-NZ1990-2014

\begin{tabular}{lllllllllll}
\hline HK & SITC 0 & $\mathbf{1}$ & $\mathbf{2}$ & $\mathbf{3}$ & $\mathbf{4}$ & $\mathbf{5}$ & $\mathbf{6}$ & $\mathbf{7}$ & $\mathbf{8}$ & $\mathbf{9}$ \\
\hline 1st sub-period & 0.06 & & 0.07 & & 0.14 & 0.58 & & 0.15 & 0.06 & \\
\hline 2nd sub-period & 0.28 & 0.26 & 0.13 & 0.05 & 0.06 & 0.05 & 0.51 & 0.10 & 0.15 & 0.41 \\
\hline 3rd sub-period & 0.51 & 0.10 & 0.20 & 0.03 & 0.43 & 0.60 & 0.27 & 0.02 & 0.09 & 0.54 \\
\hline
\end{tabular}

Table 2f. The 10-year span Brulhart MIIT index of ASEAN-New Zealand 1990-2014

\begin{tabular}{lllllllllll}
\hline Ba & SITC 0 & $\mathbf{1}$ & $\mathbf{2}$ & $\mathbf{3}$ & $\mathbf{4}$ & $\mathbf{5}$ & $\mathbf{6}$ & $\mathbf{7}$ & $\mathbf{8}$ & $\mathbf{9}$ \\
\hline 1st sub-period & 0.11 & 0.00 & 0.14 & 0.00 & 0.24 & 0.74 & 0.00 & 0.25 & 0.10 & 0.00 \\
\hline 2nd sub-period & 0.44 & 0.41 & 0.23 & 0.09 & 0.12 & 0.10 & 0.67 & 0.19 & 0.26 & 0.58 \\
\hline 3rd sub-period & 0.68 & 0.19 & 0.33 & 0.06 & 0.60 & 0.75 & 0.43 & 0.04 & 0.16 & 0.70 \\
\hline
\end{tabular}

Source: UN COMTRADE Database, 2015, Author's calculations.

Note: $1^{\text {st }}$ period refers to the 10 -year span from 1990 to $2000 ; 2^{\text {nd }}$ period refers to the 10 -year span from 2010; $3^{\text {rd }}$ period refers to the 4-years span from 2011 to 2014.

\subsection{Determinants of Australia-ASEAN IIT: Estimated Results}

The results shown in Table 4 are measured by linear-log OLS regressions. IITB, IITC and IITQ are the dependent variables and are explained by four determinants derived from Linder's hypothesis, namely: Average Development Level $(A L D)$, Average Market Size $(A M S)$, Level of Development Differential (LDDjk) and Market Size Difference (MSD) between the two countries. The estimated functions are: 


$$
\begin{aligned}
& I I T=\alpha+\beta \log A L D+\varepsilon \\
& I I T=\alpha+\beta \log A M S+\varepsilon \\
& I I T=\alpha+\beta \log L D D+\varepsilon \\
& I I T=\alpha+\beta \log M S D+\varepsilon
\end{aligned}
$$

The results in Table 4 IITB are inconsistent with IITC and IITQ. Specifically, a one-percent increase in the average level of development between the countries tends to reduce the IITB by around seven percent and increase IITC and IITQ by 9.5 percent and 6.4 percent, respectively. In addition, the coefficients of the market size difference (MSD) and the level of development differential (LDD) tend to be positive, which is inconsistent with the hypothesis. Therefore, hypotheses 1 and 2 are supported by the ASEAN-Australia evidence when IITC and IITQ are explained by the determinants. Hypotheses 3 and 4 are satisfied with positive coefficients of MSD and LDD when IITB is used as the measure of IIT. (Note: Can it be inconsistent with and at the same time satisfy the hypothesis?)

Table 5 shows the estimated results in the probit models on the likelihood of having high IIT between ASEAN and Australia. The dependent variables are three dummy variables, namely, High IITB, High IITC and High IITQ. They are equal to 1 if the level of IIT is at least 40 (for IITB) or 50 (for IITC and IITQ) and are equal to 0 if they are less than 40 (for IITB) or 50 (for IITC and IITQ).

The likelihood of having high IITB decreases as the average level of development and average market size between the two countries increases. This is inconsistent with the hypotheses 1 and 2. By contrast, hypotheses 3 and 4 can be satisfied with the negative coefficients of MSD and LDD when IITB is used as the measure of IIT. When high IITC and high IITQ are measured as the dependent variables, only hypotheses 1 and 2 can be satisfied. Hypotheses 3 and 4 are rejected by the positive coefficients of MSD and LDD.

Table 4. Determinants of IIT between ASEAN and Australia (1990-2013)

\section{$\underline{\text { IITB }}$}
OLS Regressions
(1)
(2)
(3)
(4)

\begin{tabular}{lll}
\hline $\log ($ ALD $)$ & \multicolumn{1}{l}{$-6.784 * * *$} \\
\cline { 2 - 3 } & \multicolumn{1}{c}{$(1.270)$} & \\
\hline $\log ($ AMS $)$ & $-5.307 * * *$ \\
\hline $\log ($ LDD $)$ & $(1.101)$ & \\
\hline
\end{tabular}


(0.940)

\begin{tabular}{lllll}
\hline \multirow{2}{*}{$\log (\mathrm{MSD})$} & \multicolumn{3}{c}{$-6.889^{* * * *}$} \\
\cline { 2 - 5 } & & & $(1.248)$ \\
\hline constant & $55.729^{* * *}$ & $71.981^{* * *}$ & $49.402^{* * * *}$ & $59.924 * * *$ \\
\cline { 2 - 5 } & $(3.504)$ & $(7.226)$ & $(5.209)$ & $(4.143)$ \\
\hline R squared & 56.45 & 51.36 & 20.13 & 58.06 \\
\hline Prob. F & 0.000 & 0.0001 & 0.028 & 0.000 \\
\hline No. of observations & 24 & 24 & 24 & 24 \\
\hline
\end{tabular}

\section{$\underline{\text { IITC }}$}

OLS Regressions

\begin{tabular}{|c|c|c|c|c|}
\hline \multirow{2}{*}{$\log (\mathrm{ALD})$} & \multicolumn{4}{|l|}{$9.538 * * *$} \\
\hline & $(2.927)$ & & & \\
\hline \multirow{2}{*}{$\log (\mathrm{AMS})$} & \multicolumn{3}{|c|}{$8.262 * * *$} & \\
\hline & & (2.332) & & \\
\hline \multirow{2}{*}{$\log (\mathrm{LDD})$} & & \multicolumn{3}{|c|}{$4.857 * * *$} \\
\hline & & \multicolumn{3}{|c|}{ (1.650) } \\
\hline \multirow{2}{*}{$\log (\mathrm{MSD})$} & & & & $9.586 * * *$ \\
\hline & & & & $(2.925)$ \\
\hline \multirow{2}{*}{ constant } & $27.183 * * *$ & -0.905 & $26.526^{* * *}$ & $21.610^{* *}$ \\
\hline & (8.073) & (15.308) & (9.139) & (9.708) \\
\hline $\mathrm{R}$ squared & 32.55 & 36.32 & 28.26 & 32.81 \\
\hline
\end{tabular}




\begin{tabular}{lllll}
\hline Prob. F & 0.004 & 0.002 & 0.008 & 0.003 \\
\hline No. of observations & 24 & 24 & 24 & 24 \\
\hline
\end{tabular}

\section{IITQ}

\section{OLS Regressions}

$$
\log \text { (ALD) }
$$

(2)

(3)

(4)

\section{$6.447 * * *$}

(1.879)

\section{$5.712 * * *$}

$\log (\mathrm{AMS})$

$(1.471)$

\section{$3.750 * * *$}

$\log (\mathrm{LDD})$

(0.990)

$6.430 * * *$

$\log (\mathrm{MSD})$

(1.885)

\begin{tabular}{lllll}
\hline \multirow{2}{*}{ constant } & $31.787^{* * *}$ & 11.969 & $28.781^{* * * *}$ & 28.183 *** \\
\cline { 2 - 5 } & $(5.183)$ & $(9.652)$ & $(5.484)$ & $(6.258)$ \\
\hline R squared & 34.85 & 40.68 & 39.49 & 34.59 \\
\hline Prob. F & 0.002 & 0.000 & 0.001 & 0.003 \\
\hline No. of observations & 24 & 24 & 24 & 24 \\
\hline
\end{tabular}

Standard errors are in parentheses

* Significant at $10 \%$

** Significant at 5\%

*** Significant at $1 \%$ 
Table 5. Determinants of IIT between ASEAN and Australia (1990-2013)

\section{$\underline{\text { High IITB }(\geq 40)}$}

Probit Regressions

(1)

(2)

(3)

(4)

$-0.262$

ALD

$(0.166)$

$$
-0.003^{*}
$$

AMS

$$
(0.002)
$$

$$
-0.003
$$

LDD

$$
\text { (0.002) }
$$

$-0.170$

MSD

$(0.113)$

\begin{tabular}{lllll}
\hline \multirow{2}{*}{ constant } & 2.969 & 1.651 & 0.350 & 3.399 \\
\cline { 2 - 5 } & $(1.894)$ & $(1.078)$ & $(0.507)$ & $(2.235)$ \\
\hline R squared & 34.19 & 28.79 & 11.70 & 36.48 \\
\hline LR test & 10.45 & 8.80 & 3.58 & 11.15 \\
\hline No. of observations & 24 & 24 & 24 & 24 \\
\hline
\end{tabular}

\section{$\underline{\text { High IITC }(\geq 50)}$}

Probit Regressions

ALD

(1)

(2)

(3)

(4)

\section{$0.688^{*}$}

(0.374) 
(0.005)

\begin{tabular}{|c|c|c|c|c|}
\hline \multirow{2}{*}{ LDD } & & \multicolumn{3}{|c|}{$0.006^{*}$} \\
\hline & & \multicolumn{3}{|c|}{$(0.003)$} \\
\hline \multirow{2}{*}{ MSD } & & & & $0.424 *$ \\
\hline & & & & $(0.224)$ \\
\hline \multirow{2}{*}{ constant } & $-7.438 *$ & $-5.112 *$ & -0.895 & $-8.072 *$ \\
\hline & $(4.082)$ & (2.629) & $(0.726)$ & $(4.306)$ \\
\hline $\mathrm{R}$ squared & 45.76 & 49.16 & 26.21 & 46.77 \\
\hline LR test & 13.26 & 14.24 & 7.59 & 13.55 \\
\hline No. of observations & 24 & 24 & 24 & 24 \\
\hline
\end{tabular}

\section{High IITQ ( $\geq \mathbf{5 0})$}

Probit Regressions

\begin{tabular}{|c|c|c|c|c|}
\hline \multirow{2}{*}{ ALD } & \multicolumn{4}{|l|}{$0.080 * *$} \\
\hline & $(0.036)$ & & & \\
\hline \multirow{2}{*}{ AMS } & \multicolumn{3}{|c|}{$0.001 * *$} & \\
\hline & & $(0.001)$ & & \\
\hline \multirow{2}{*}{ LDD } & & \multicolumn{3}{|c|}{$0.003 * *$} \\
\hline & & \multicolumn{3}{|c|}{$(0.001)$} \\
\hline \multirow{2}{*}{ MSD } & & & & $0.046 * *$ \\
\hline & & & & $(0.021)$ \\
\hline constant & $-1.199 *$ & $-0.982 *$ & -7.250 & -1.213 \\
\hline
\end{tabular}


$(0.633)$

$(0.545)$

$(0.459)$

$(0.636)$

\begin{tabular}{lllll}
\hline R squared & 17.21 & 17.51 & 13.64 & 17.45 \\
\hline LR test & 5.70 & 5.80 & 4.52 & 5.78 \\
\hline No. of observations & 24 & 24 & 24 & 24 \\
\hline
\end{tabular}

Standard errors are in parentheses

* Significant at $10 \%$

** Significant at $5 \%$

*** Significant at $1 \%$

\section{Conclusion}

Our results show that inter-industry and intra-industry trade between ASEAN and Australia and ASEAN and New Zealand exist simultaneously across sectors, with inter-industry trade being dominant compared to intra-industry trade. In other words, the countries/regions involved have a comparative advantage in exporting in particular sectors or industries and not in specific products within industries or sectors. Australia has a comparative advantage in exporting crude materials and mineral fuels, resulting in a large trade deficit for ASEAN and leading to low levels of IIT between ASEAN and Australia.

Similarly, New Zealand has a comparative advantage in exporting food and live animals and crude materials to ASEAN. By contrast, there is a consistently high IIT trade in machinery and transport equipment between ASEAN and Australia and also between ASEAN and New Zealand. IIT between ASEAN and New Zealand strengthened in beverage, tobacco and mineral fuels, and so did IIT between Australia and ASEAN, increasing from 40 to 60 per cent. The greatest number of high IIT is in the machinery and transport equipment sectors.

Marginal intra-industry trade results indicate a high degree of bilateral trade in food and beverages and manufacturing between Australia and ASEAN. These results demonstrate that export and import sectors changed by more or less the same amount, suggesting the small adjustment costs of trade. In addition, intra-industry trade between ASEAN and New Zealand strengthened in beverage and tobacco, and mineral fuels. SITC 6 (Manufactured goods) and 7 (Machinery and transport equipment) had a large number of high IIT sectors between ASEAN and New Zealand in 2014. Marginal intra-industry trade results further suggest that bilateral trade in SITC food and live animals and chemicals between ASEAN and New Zealand tend to high intra-industry trade. The likelihood of experiencing a high IIT decreases as the average level of development and average market size between the countries increases. 
After increasing significantly during 2000-2010, the IIT index between ASEAN and Australia weakened from 2010 to 2014, for reasons that still need to be examined. Since 2010 happened to be the year when AANZFTA became operational, this raises the issue of whether the weakening was due to AANZFTA. If so, this would be a paradoxical result, since AANZFTA was precisely aimed at promoting trade, both inter and intra-industry, amongst the three trade partners.

The results of our regression analysis on the determinants of intra-industry trade provide some support to the thesis that increase in IIT comes naturally with development. As a country's level of income goes up and its standard of living rise, its citizens will demand and consume more differentiated products, leading to higher levels of intra-industry trade.

ASEAN member-countries have been growing rapidly during the past decades, with their citizens enjoying higher per capita incomes and standards of living. If these trends continue, it is reasonable to expect that, despite occasional recent reversals, trade in general and intra-industry trade in particular will continue to expand.

\section{Acknowledgments}

The author expresses sincere thanks to, School of Accounting, Finance and Economics and the University of Waikato, New Zealand for their support and encouragement. My sincere thanks to Professor Jose Tabbada for his valuable suggestions. The Author is grateful to the Editor and the anonymous referee for their valuable comments and suggestions.

Any errors and Omissions are my own.

\section{References}

Annicchiarico, B., \& Quintieri, B. (2000). Aggregated Measures of Intra-Industry Trade: A Critical Comparison. Mimeo.

Aquino, A. (1978). Intra-industry trade and inter-industry specialization as concurrent sources of international trade in manufactures. Weltwirtschaftliches Archiv, 114, 275-296.

Azhar, A. K. M., \& Elliott, R. J. R. (2006). On the Measurement of Product Quality in Intra-Industry Trade. Review of World Economics, 142(3), 476-495.

Balassa, B. (1966). Tariff Reductions and Trade in Manufactures among the Industrial Countries. The American Economic Review, 56, 466-473.

Brülhart, M. (1994). Marginal Intra-Industry Trade: Measurement and Relevance for the Pattern of Industrial Adjustment. Weltwirtschaftliches Archiv, 130(3), 600-613.

Brülhart, M., \& Elliott, R. J. (2002). Labour-market effects of intra-industry trade: evidence for the United Kingdom. Weltwirtschaftliches Archiv, 138(2), 207-228.

Fontagné, L., Freudenberg, M., \& Gaulier, G. (2006). A systematic decomposition of world trade into horizontal and vertical IIT. Review of World Economics, 142(3), 459-475.

Greenaway, D., Hine, R., \& Milner, C. (1994). Country-specific factors and the pattern of 


\section{$\triangle$ Macrothink}

International Journal of Accounting and Financial Reporting

ISSN 2162-3082

2018, Vol. 8, No. 4

horizontal and vertical intra-industry trade in the UK. Weltwirtschaftliches Archiv, 130(1), 77-100.

Greenaway, D., \& Milner, C. R. (1995). Vertical and Horizontal Intra-Industry Trade: A Cross Industry Analysis for the United Kingdom. The Economic Journal, 105(433), 1505-1518.

Greenaway, D., Morgan, W., \& Wright, P. (2002). Trade liberalisation and growth in developing countries. Journal of Development Economics, 67(1), 229-244.

Grubel, H. G., \& Lloyd, P. J. (1975). Intra Industry Trade: The theory and measurement of international trade in differentiated products. London: Macmillan.

Hamilton, C., \& Kniest, P. (1991). Trade liberalisation, structural adjustment and intra-industry trade: a note. Weltwirtschaftliches Archiv, 127, 356-67.

He, Y., \& Yu, S. (2013). Empirical Analysis on Influence Factors of Agricultural Intra-industry Trade from Guangxi and ASEAN Regions. International Journal of Advancements in Computing Technology, 5(7).

Jambor, A. (2014). Country - Specific Determinants of Horizontal and Vertical Intra-industry Agri-food Trade: The Case of the EU New Member States. Journal of Agricultural Economics, 65(3), 663-682.

Kojima, K. (1964). The pattern of international trade among advanced countries. Hitotsubashi. Journal of Economics, 5(1), 16-36.

Krugman, P. (1979). Increasing Returns, Monopolistic Competition and International Trade. Journal of International Economics, 9, 469-479.

Łapińska, J. (2015). The Economic Integration as a Determinants of Intra-Industry Trade-: The Case of Poland. Scientific Papers of the University of Pardubice, 77.

Linder, S. B. (1961). An essay on trade and transformation (pp. 82-109). Stockholm Almqvist\&Wiksell.

Phan, T. H., \& JiJeong, Y. (2014). An empirical analysis of intra industry trade in manufactures between Korea and ASEAN. Journal of Economic Studies, 41(6), 833-848.

Sawyer, W. C., Sprinkle, R. L., \& Tochkov, K. (2010). Patterns and determinants of intra-industry trade in Asia. Journal of Asian Economics, 21(5), 485-493.

Soo, K. T. (2016). Intra-industry trade: A Krugman-Ricardo model and data. Economica, 83, 338-355.

The World Bank. (2014, 2015). World Development Indicators. World Databank. Retrieved from http://databank.worldbank.org/data/home.aspx

Thom, R., \& McDowell, M. (1999). Measuring marginal intra-industry trade. Weltwirtschaftliches Archiv, 135(1), 48-61.

Thorpe, M., \& Leitão, N. C. (2012). Marginal Intra - Industry Trade and Adjustment Costs: 


\section{Mll Macrothink}

International Journal of Accounting and Financial Reporting

ISSN 2162-3082

2018, Vol. 8, No. 4

The Australian Experience. Economic Papers: A journal of applied economics and policy, $31(1), 123-131$.

United Nations Commodity Trade (UN Comtrade). (2014, 2015). Data query. UN Comtrade Statistics Database. Retrieved from http://comtrade.un.org/db/default.aspx

United Nations Conference of Trade and Development (UNCTAD). (2015). Trade trends and economic trends. UNCTAD STAT. Retrieved from http://unctadstat.unctad.org/EN/Index.html

Varma, P., \& Ramakrishnan, A. (2014). An Analysis of the Structure and the Determinants of Intra-industry Trade in Agri-food Products: Case of India and Selected FTAs. Millennial Asia, 5(2), 179-196.

Wagner, J. (2017). Intra-good trade in Germany: a first look at the evidence. Applied Economics, 49(57), 5753-5761.

\section{Appendix A}

A1: Grubel-Lloyd Index

The Grubel-Lloyd Index (1975) single industry intra-industry equation is:

$$
\operatorname{IITB}_{i}=\frac{\left(X_{i}+M_{i}\right)-\left|X_{i}-M_{i}\right|}{X_{i}} \times 100
$$

where $X_{i}$ and $M_{\mathrm{i}}$ are exports and imports of industry $i$ of a country.

For aggregated industry or product group, the index will be a weighted average of $I I T B_{i}$, the weight being the share of each industry in the country's total trade. The summary Grubel-Lloyd index is:

$$
I I T B=\overline{I I T B}_{i}=\frac{\sum_{i=1}^{n}\left(X_{i}+M_{i}\right)-\sum_{i=1}^{n}\left|X_{i}-M_{i}\right|}{\sum_{i=1}^{n}\left(X_{i}+M_{i}\right)} \times 100
$$

Where, IITBi is the weighted average of the value of $I I T B_{i}$ across industries $i=1 \ldots \mathrm{n}$, and $n$ is the number of industries in the sample. $I I T B_{i}$ is an accurate measure if there is balanced bilateral trade. However, as discussed above, when the total trade is unbalanced, the index will be biased downward, so the imbalance needs to be adjusted, and the modified formula is: 


$$
I I T C=\frac{\sum_{i=1}^{n}\left(X_{i}+M_{i}\right)-\sum_{i=1}^{n}\left|X_{i}-M_{i}\right|}{\sum_{i=1}^{n}\left(X_{i}+M_{i}\right)-\left|\sum_{i=1}^{n} X_{i}-\sum_{i=1}^{n} M_{i}\right|} \times 100
$$

\section{A2: Aquino Adjusted Index}

To avoid the imbalance bias, Aquino (1978) suggested another modification in the industry level. The 'theoretical values' of exports and imports can be estimated by the formulas :

$$
X_{i}^{e}=X_{i} \frac{1}{2} \frac{\sum_{i=1}^{n}\left(X_{i}+M_{i}\right)}{\sum_{i=1}^{n} X_{i}} M_{i}^{e}=M_{i} \frac{1}{2} \frac{\sum_{i=1}^{n}\left(X_{i}+M_{i}\right)}{\sum_{i=1}^{n} M_{i}}
$$

By replacing the actual exports and imports with the above values in the Grubel-Lloyd equation, Aquino adjusted index $\left(I I T Q_{i}\right)$ can be written as:

$$
I I T Q=\frac{\sum_{i=1}^{n}\left(X_{i}^{e}+M_{i}^{e}\right)-\sum_{i=1}^{n}\left|X_{i}^{e}-M_{i}^{e}\right|}{\sum_{i=1}^{n}\left(X_{i}^{e}+M_{i}^{e}\right)} \times 100
$$

\section{Appendix B}

B1a. ASEAN trade with Australia in SITC 1-digit commodities: 1995-2013 (US\$ Millions)

\begin{tabular}{lllllllllll}
\hline Year & SITC 0 & SITC 1 & SITC 2 & SITC 3 & SITC 4 & SITC 5 & SITC 6 & SITC 7 & SITC 8 & SITC 9 \\
\hline 1995 & 450 & 7 & 209 & 897 & 100 & 322 & 734 & 2,164 & 709 & 123 \\
1996 & 465 & 7 & 174 & 1,245 & 82 & 376 & 781 & 2,561 & 668 & 67 \\
1997 & 484 & 7 & 144 & 1,374 & 83 & 411 & 757 & 2,789 & 748 & 348 \\
1998 & 431 & 5 & 125 & 1,092 & 91 & 446 & 757 & 2,998 & 1,010 & 621 \\
1999 & 506 & 5 & 147 & 2,060 & 80 & 542 & 998 & 3,501 & 955 & 261 \\
2000 & 466 & 6 & 181 & 3,026 & 65 & 616 & 979 & 3,954 & 1,000 & 279 \\
2001 & 447 & 8 & 142 & 3,085 & 52 & 604 & 895 & 3,175 & 930 & 567 \\
2002 & 493 & 23 & 168 & 3,517 & 71 & 691 & 956 & 3,548 & 1,014 & 605 \\
2003 & 637 & 19 & 198 & 4,278 & 80 & 817 & 1,109 & 4,127 & 1,514 & 668 \\
2004 & 709 & 35 & 200 & 6,771 & 100 & 947 & 1,507 & 5,473 & 1,609 & 707 \\
2005 & 829 & 50 & 200 & 9,811 & 100 & 1,082 & 1,708 & 6,313 & 1,468 & 843 \\
2006 & 915 & 69 & 257 & 11,233 & 127 & 1,248 & 2,054 & 7,493 & 1,665 & 1,916 \\
2007 & 1,083 & 89 & 310 & 13,141 & 163 & 1,513 & 2,289 & 9,149 & 1,832 & 2,056 \\
2008 & 1,334 & 100 & 315 & 17,377 & 249 & 1,811 & 3,037 & 9,762 & 2,087 & 3,007 \\
2009 & 1,286 & 109 & 240 & 10,285 & 186 & 1,415 & 3,629 & 8,714 & 1,959 & 3,645 \\
2010 & 1,504 & 156 & 293 & 13,700 & 219 & 2,006 & 3,267 & 11,260 & 2,479 & 2,917
\end{tabular}




\begin{tabular}{lllllllllll}
2011 & 1,862 & 209 & 349 & 17,881 & 308 & 2,783 & 3,203 & 10,975 & 2,967 & 1,750 \\
2012 & 1,894 & 283 & 341 & 18,445 & 253 & 2,998 & 4,086 & 12,223 & 3,153 & 2,265 \\
2013 & 2,395 & 295 & 337 & 17,218 & 222 & 2,772 & 4,592 & 12,916 & 3,591 & 924 \\
\hline
\end{tabular}

Source: UNCTAD Stat Database, 2015, Author's calculations.

B2a. Australia trade with ASEAN:

1990-2013 (US\$ Millions)

\begin{tabular}{|c|c|c|c|}
\hline Year & Exports & Imports & Total \\
\hline 1990 & 4,099 & 2,280 & 6,379 \\
\hline 1991 & 4,700 & 2,951 & 7,651 \\
\hline 1992 & 5,575 & 3,365 & 8,940 \\
\hline 1993 & 5,294 & 3,377 & 8,671 \\
\hline 1994 & 6,373 & 4,075 & 10,447 \\
\hline 1995 & 7,663 & 4,989 & 12,652 \\
\hline 1996 & 8,028 & 5,977 & 14,005 \\
\hline 1997 & 8,475 & 6,623 & 15,097 \\
\hline 1998 & 5,349 & 7,249 & 12,597 \\
\hline 1999 & 6,417 & 9,013 & 15,430 \\
\hline 2000 & 8,729 & 9,524 & 18,252 \\
\hline 2001 & 7,916 & 9,037 & 16,953 \\
\hline 2002 & 7,905 & 10,453 & 18,358 \\
\hline 2003 & 7,849 & 13,145 & 20,994 \\
\hline 2004 & 10,058 & 17,005 & 27,063 \\
\hline 2005 & 12,032 & 21,397 & 33,429 \\
\hline 2006 & 14,126 & 25,617 & 39,743 \\
\hline 2007 & 15,000 & 30,626 & 45,626 \\
\hline 2008 & 19,210 & 40,449 & 59,660 \\
\hline 2009 & 15,252 & 31,079 & 46,331 \\
\hline 2010 & 19,381 & 36,630 & 56,011 \\
\hline 2011 & 27,514 & 42,862 & 70,376 \\
\hline 2012 & 26,383 & 46,889 & 73,272 \\
\hline 2013 & 21,947 & 42,561 & 64,508 \\
\hline
\end{tabular}

B2b. NZ trades with ASEAN: 1990-2013 (US\$ Millions)

\begin{tabular}{|c|c|c|c|}
\hline Year & Exports & Imports & Total \\
\hline 1990 & 545 & 368 & 913 \\
\hline 1991 & 659 & 314 & 973 \\
\hline 1992 & 786 & 462 & 1,247 \\
\hline 1993 & 723 & 438 & 1,161 \\
\hline 1994 & 817 & 565 & 1,382 \\
\hline 1995 & 1,050 & 837 & 1,888 \\
\hline 1996 & 1,170 & 886 & 2,056 \\
\hline 1997 & 1,239 & 819 & 2,058 \\
\hline 1998 & 811 & 764 & 1,574 \\
\hline 1999 & 911 & 1,035 & 1,946 \\
\hline 2000 & 1,133 & 994 & 2,127 \\
\hline 2001 & 1,260 & 1,151 & 2,411 \\
\hline 2002 & 1,107 & 1,275 & 2,382 \\
\hline 2003 & 1,291 & 1,571 & 2,862 \\
\hline 2004 & 1,525 & 2,243 & 3,769 \\
\hline 2005 & 1,663 & 2,874 & 4,537 \\
\hline 2006 & 1,909 & 3,553 & 5,462 \\
\hline 2007 & 2,737 & 4,181 & 6,918 \\
\hline 2008 & 3,324 & 5,354 & 8,679 \\
\hline 2009 & 2,584 & 3,360 & 5,944 \\
\hline 2010 & 3,102 & 4,369 & 7,472 \\
\hline 2011 & 3,527 & 5,195 & 8,722 \\
\hline 2012 & 3,509 & 6,304 & 9,813 \\
\hline 2013 & 3,905 & 6,377 & 10,282 \\
\hline
\end{tabular}

Source: UNCTAD Stat Database, 2015, Author's calculations.

B3. NZ total trade with ASEAN in SITC 1-digit commodities: 1995-2013 (in US\$ Millions)

\begin{tabular}{lllllllllll}
\hline Year & SITC 0 & SITC 1 & SITC 2 & SITC 3 & SITC 4 & SITC 5 & SITC 6 & SITC 7 & SITC 8 & SITC 9 \\
\hline 1995 & 647 & 2 & 179 & 182 & 32 & 78 & 259 & 397 & 115 & 0 \\
1996 & 740 & 2 & 192 & 197 & 31 & 102 & 277 & 393 & 127 & 0 \\
1997 & 800 & 2 & 171 & 119 & 30 & 118 & 259 & 427 & 137 & 0 \\
1998 & 600 & 2 & 105 & 89 & 22 & 84 & 171 & 394 & 111 & 0 \\
1999 & 657 & 2 & 134 & 107 & 23 & 125 & 230 & 515 & 153 & 5 \\
2000 & 813 & 4 & 168 & 99 & 19 & 163 & 215 & 505 & 152 & 0 \\
2001 & 1,010 & 4 & 120 & 269 & 18 & 175 & 221 & 460 & 145 & 0 \\
2002 & 843 & 5 & 128 & 277 & 23 & 188 & 257 & 504 & 157 & 9 \\
2003 & 1,020 & 6 & 155 & 360 & 28 & 217 & 304 & 580 & 193 & 5
\end{tabular}




\begin{tabular}{lllllllllll}
2004 & 1,181 & 8 & 206 & 679 & 38 & 250 & 382 & 781 & 241 & 9 \\
2005 & 1,317 & 10 & 229 & 1,024 & 37 & 303 & 389 & 962 & 258 & 12 \\
2006 & 1,420 & 11 & 305 & 1,587 & 43 & 317 & 395 & 1,104 & 264 & 19 \\
2007 & 2,160 & 17 & 344 & 1,744 & 56 & 384 & 457 & 1,457 & 289 & 18 \\
2008 & 2,641 & 20 & 393 & 2,573 & 82 & 471 & 533 & 1,632 & 317 & 28 \\
2009 & 1,870 & 19 & 300 & 1,629 & 60 & 352 & 380 & 1,024 & 299 & 23 \\
2010 & 2,696 & 30 & 375 & 1,781 & 68 & 410 & 522 & 1,224 & 343 & 42 \\
2011 & 3,197 & 45 & 424 & 2,114 & 120 & 491 & 584 & 1,297 & 404 & 75 \\
2012 & 3,080 & 69 & 428 & 3,021 & 118 & 542 & 577 & 1,503 & 434 & 68 \\
2013 & 3,418 & 69 & 420 & 2,617 & 146 & 604 & 596 & 1,667 & 469 & 115 \\
\hline
\end{tabular}

Source: UNCTAD Stat Database, 2015. Author's calculations

B4. ASEAN Total Trade with the Rest of the World in SITC 1-digit Commodities: 1995-2013 (in US\$ Millions)

\begin{tabular}{lllllllllll} 
Year & SITC 0 & SITC 1 & SITC 2 & SITC 3 & SITC 4 & SITC 5 & SITC 6 & SITC 7 & SITC 8 & SITC 9 \\
\hline 1995 & 28,798 & 3,432 & 21,925 & 36,935 & 6,977 & 35,485 & 69,372 & 253,712 & 54,702 & 20,649 \\
1996 & 30,048 & 3,918 & 21,615 & 45,709 & 6,624 & 35,305 & 69,995 & 279,655 & 58,110 & 9,401 \\
1997 & 30,041 & 4,175 & 19,700 & 47,437 & 7,416 & 36,464 & 68,318 & 288,318 & 57,547 & 16,324 \\
1998 & 26,696 & 3,476 & 15,574 & 35,616 & 7,408 & 31,057 & 51,895 & 246,889 & 50,432 & 16,658 \\
1999 & 27,677 & 2,725 & 16,226 & 44,259 & 6,829 & 35,369 & 57,747 & 266,437 & 56,661 & 9,707 \\
2000 & 28,693 & 2,458 & 18,866 & 64,127 & 5,552 & 40,759 & 64,392 & 322,157 & 65,051 & 12,246 \\
2001 & 29,451 & 2,328 & 16,824 & 58,470 & 5,034 & 38,921 & 59,926 & 284,750 & 61,870 & 12,695 \\
2002 & 30,503 & 2,311 & 17,909 & 58,060 & 7,442 & 42,354 & 63,242 & 299,430 & 62,866 & 13,146 \\
2003 & 32,090 & 2,342 & 20,631 & 69,688 & 9,512 & 51,320 & 67,491 & 325,594 & 68,955 & 14,395 \\
2004 & 36,485 & 2,702 & 25,676 & 93,942 & 11,454 & 64,014 & 86,049 & 395,030 & 81,208 & 16,658 \\
2005 & 40,850 & 3,113 & 30,288 & 127,272 & 11,613 & 73,956 & 101,605 & 439,823 & 87,835 & 21,252 \\
2006 & 46,606 & 3,425 & 39,484 & 152,217 & 13,394 & 84,968 & 116,964 & 501,301 & 99,593 & 28,624 \\
2007 & 55,963 & 4,186 & 45,924 & 168,093 & 21,246 & 96,902 & 140,082 & 542,580 & 110,403 & 36,117 \\
2008 & 71,547 & 5,015 & 52,429 & 252,798 & 32,032 & 108,897 & 160,741 & 557,314 & 122,519 & 75,908 \\
2009 & 66,761 & 4,791 & 39,152 & 169,942 & 23,795 & 95,578 & 123,440 & 483,269 & 111,267 & 41,957 \\
2010 & 78,507 & 5,531 & 61,213 & 231,161 & 31,812 & 128,912 & 163,234 & 602,858 & 138,289 & 64,416 \\
2011 & 98,620 & 7,203 & 82,596 & 328,125 & 42,800 & 164,907 & 198,670 & 641,682 & 162,822 & 85,039 \\
2012 & 100,956 & 7,988 & 69,760 & 332,468 & 39,480 & 168,498 & 202,127 & 701,565 & 172,242 & 67,899 \\
2013 & 108,038 & 8,645 & 71,619 & 328,227 & 36,247 & 167,237 & 219,194 & 706,063 & 185,800 & 65,348 \\
\hline
\end{tabular}

Source: UNCTAD Stat Database, 2015, Author's calculations.

B5. Australia total trades with the rest of the world in SITC 1-digit commodities: 1995-2013 (in US\$ Millions)

SITC

\begin{tabular}{lllllllllll} 
Year & SITC 0 & SITC 1 & $\mathbf{2}$ & SITC 3 & SITC 4 & SITC 5 & SITC 6 & SITC 7 & SITC 8 & SITC 9 \\
\hline 1,995 & 11,871 & 805 & 11,778 & 11,760 & 383 & 8,478 & 15,667 & 33,771 & 9,975 & 5,521 \\
1,996 & 14,667 & 978 & 12,513 & 14,022 & 400 & 9,404 & 15,694 & 36,630 & 10,859 & 5,957 \\
1,997 & 15,127 & 1,064 & 13,462 & 14,829 & 401 & 9,298 & 15,906 & 37,089 & 11,376 & 5,629 \\
1,998 & 11,802 & 1,095 & 11,890 & 12,189 & 410 & 9,024 & 14,714 & 34,566 & 11,209 & 9,265 \\
1,999 & 12,718 & 1,338 & 11,388 & 13,147 & 393 & 9,982 & 15,139 & 37,866 & 11,668 & 5,593 \\
2,000 & 13,332 & 1,484 & 12,940 & 18,823 & 339 & 10,311 & 16,058 & 38,785 & 11,947 & 7,508 \\
2,001 & 13,402 & 1,610 & 12,648 & 18,304 & 308 & 10,206 & 14,531 & 34,153 & 11,165 & 7,911
\end{tabular}




\begin{tabular}{lllllllllll}
\hline 2,002 & 14,107 & 1,951 & 12,349 & 18,514 & 357 & 10,671 & 15,827 & 39,577 & 12,431 & 8,750 \\
2,003 & 14,020 & 2,336 & 13,616 & 20,477 & 444 & 12,950 & 17,741 & 46,718 & 14,760 & 12,007 \\
2,004 & 18,865 & 2,863 & 17,520 & 27,086 & 549 & 15,858 & 21,115 & 55,895 & 17,854 & 12,592 \\
2,005 & 18,677 & 3,048 & 23,556 & 40,304 & 523 & 18,450 & 23,677 & 62,667 & 19,614 & 14,156 \\
2,006 & 19,938 & 3,236 & 30,501 & 47,156 & 620 & 19,195 & 27,720 & 66,253 & 21,015 & 20,339 \\
2,007 & 20,426 & 3,877 & 35,947 & 51,823 & 796 & 23,117 & 33,010 & 76,980 & 24,462 & 24,341 \\
2,008 & 25,393 & 3,741 & 48,786 & 89,964 & 1,053 & 26,933 & 36,456 & 87,593 & 28,065 & 30,452 \\
2,009 & 23,808 & 3,418 & 40,920 & 65,507 & 834 & 23,400 & 27,952 & 69,998 & 25,634 & 31,236 \\
2,010 & 26,475 & 3,705 & 68,516 & 85,676 & 958 & 27,333 & 34,201 & 85,021 & 28,867 & 34,693 \\
2,011 & 34,533 & 4,156 & 99,227 & 115,331 & 1,252 & 32,739 & 42,155 & 99,801 & 34,267 & 40,169 \\
2,012 & 35,982 & 4,299 & 89,380 & 115,222 & 1,154 & 33,582 & 41,224 & 112,928 & 35,164 & 37,772 \\
2,013 & 36,427 & 4,374 & 98,739 & 105,888 & 1,153 & 30,362 & 39,659 & 101,649 & 34,916 & 31,470 \\
\hline
\end{tabular}

Source: UNCTAD Stat Database, 2015. Author's calculations.

B6. NZ total trade with the rest of the world in SITC 1-digit commodities: 1995-2013 (in US\$ Millions)

\begin{tabular}{lllllllllll}
\hline & SITC & SITC & SITC & SITC & SITC & SITC & SITC & SITC & SITC & SITC \\
Year & $\mathbf{0}$ & $\mathbf{1}$ & $\mathbf{2}$ & $\mathbf{3}$ & $\mathbf{4}$ & $\mathbf{5}$ & $\mathbf{6}$ & $\mathbf{7}$ & $\mathbf{8}$ & $\mathbf{9}$ \\
\hline 1995 & 6,465 & 204 & 2,978 & 962 & 175 & 2,872 & 4,241 & 7,063 & 2,378 & 366 \\
1996 & 7,156 & 228 & 2,873 & 1,251 & 164 & 2,906 & 4,265 & 7,340 & 2,514 & 383 \\
1997 & 7,051 & 256 & 2,613 & 1,248 & 157 & 2,926 & 4,142 & 7,243 & 2,655 & 311 \\
1998 & 6,231 & 241 & 2,025 & 999 & 146 & 2,218 & 3,171 & 6,104 & 2,043 & 244 \\
1999 & 6,364 & 282 & 2,069 & 1,149 & 136 & 2,666 & 3,765 & 7,463 & 2,542 & 355 \\
2000 & 6,441 & 319 & 2,293 & 1,828 & 119 & 2,883 & 3,749 & 6,876 & 2,440 & 255 \\
2001 & 7,185 & 322 & 2,144 & 1,680 & 112 & 3,001 & 3,578 & 6,386 & 2,399 & 229 \\
2002 & 7,468 & 377 & 2,314 & 1,742 & 135 & 3,008 & 3,944 & 7,405 & 2,717 & 316 \\
2003 & 8,673 & 482 & 2,502 & 2,047 & 152 & 3,391 & 4,675 & 9,441 & 3,406 & 315 \\
2004 & 10,809 & 627 & 2,971 & 2,825 & 186 & 3,962 & 5,826 & 11,728 & 4,196 & 407 \\
2005 & 11,873 & 734 & 2,961 & 3,724 & 167 & 4,230 & 6,149 & 13,164 & 4,410 & 549 \\
2006 & 12,063 & 814 & 3,120 & 4,517 & 171 & 4,138 & 6,268 & 12,580 & 4,538 & 625 \\
2007 & 14,775 & 1,066 & 3,535 & 5,636 & 236 & 4,926 & 7,199 & 14,355 & 5,323 & 771 \\
2008 & 16,995 & 1,164 & 3,993 & 8,175 & 338 & 5,685 & 7,278 & 14,419 & 5,492 & 1,407 \\
2009 & 14,465 & 1,085 & 3,005 & 4,912 & 225 & 4,402 & 5,285 & 10,974 & 4,838 & 1,308 \\
2010 & 17,955 & 1,330 & 4,130 & 6,078 & 266 & 4,896 & 6,513 & 12,541 & 5,548 & 1,832 \\
2011 & 22,118 & 1,534 & 5,104 & 8,179 & 346 & 5,821 & 7,495 & 14,820 & 6,142 & 2,185 \\
2012 & 22,088 & 1,697 & 5,145 & 8,534 & 361 & 6,117 & 7,264 & 15,680 & 6,516 & 2,146 \\
2013 & 24,124 & 1,758 & 5,785 & 8,017 & 342 & 6,147 & 7,242 & 16,297 & 6,629 & 2,085
\end{tabular}

Source: UNCTAD Stat Database, 2015, Author's calculations.

B7. ASEAN-Australia intra industry trade by industry: 3-digit SITC (high category) in 2014

\begin{tabular}{|c|c|c|c|c|c|c|c|}
\hline SITC & Description & IITBi & SITC & Descrip & & & IITBi \\
\hline 001 & $\begin{array}{l}\text { Live Animals Other Than Animals Of } \\
\text { Division } 03\end{array}$ & 66.04 & 061 & $\begin{array}{l}\text { Sugars, } \\
\text { Honey }\end{array}$ & Molasses, & And & 97.88 \\
\hline 043 & Barley, Unmilled & 69.86 & 072 & Cocoa & & & 92.90 \\
\hline 059 & $\begin{array}{l}\text { Fruit Juices (Incl. Grape Must) And } \\
\text { Vegetable Juices }\end{array}$ & 93.45 & & & & & \\
\hline
\end{tabular}


$111 \quad$ Nonalcoholic Beverages, N.E.S.

Organo-Inorganic

Compounds, Heterocyclic Compounds, Nucleic Acids And Their Salts

Metallic Salts And Peroxysalts Of Inorganic Acids

Inorganic Chemicals, N.E.S.; Organic

And Inorganic Compounds Of

Precious Metals

Synthetic Organic Coloring Matter

531 And Color Lakes And Preparations

Based Thereon

633

Cork Manufactures

634

Veneers, Plywood, Particle Board, And Other Wood, Worked, N.E.S.

Woven Fabrics Of Manmade Textile Materials
Knitted Or Crocheted Fabrics

Pearls, Precious And Semiprecious

Stones, Unworked Or Worked

Steam Or Other Vapor Generating

Boilers Thereof

$82.00 \quad 747$

Power Generating Machinery And

Parts Thereof, N.E.S.

Civil Engineering And Contractors' Plant And Equipment

$58.98 \quad 748$ $97.80 \quad 749$
50.05

79.93273 Stone, Sand And Gravel

80.10

$67.04 \quad 431$

Animal Or Vegetable Fats And Oils Processed; Waxes 69.86 And Inedible Mixtures

Medicinal

And

Pharmaceutical Products,

Other Than Medicaments

66.06

(Of Group 542)

Tubes, Pipes And Hoses Of Plastics

Starches, Inulin And Wheat

Gluten; Albuminoidal

Substances; Glues

Explosives And Pyrotechnic

Products

$61.64 \quad 598$

Miscellaneous Chemical

Products, N.E.S.

Alloy Steel Flat-Rolled Products

Nails, Screws, Nuts, Bolts,

Rivets And Similar Articles, Of Iron, Steel, Copper Or 97.57 Aluminum

$93.08 \quad 695$

Tools For Use In The Hand Or In Machines

Taps, Cocks, Valves And Similar Appliances For Pipes 64.52 Transmission Shafts And Cranks

Nonelectric Parts And N.E.S. 
Paper Mill And Pulp Mill Machinery, Paper Cutting Machines

726

Printing And Bookbinding Machinery, And Parts Thereof

Food-Processing Machines (Excluding Domestic)

Machinery And Equipment Specialized For Particular Industries

Pumps For Liquids

Mechanical Handling Equipment, And Parts Thereof, N.E.S.

Nonelectrical Machinery, Tools And Mechanical Apparatus

Measuring, Checking, Analysing And Controlling Instruments An Apparatus, N.E.S.

Arms And Ammunition

Printed Matter

Coin (Other Than Gold Coin), Not Being Legal Tender
Electrical Apparatus For

$51.93 \quad 772$

Switching Or Protecting 59.48

Electrical Circuits

Electro-Diagnostic

$66.81 \quad 774$

Apparatus For Medical, 97.42

Surgical, Dental

Thermionic, Cold Cathode

Or Photocathode Valve

89.09

83.21776

$50.03 \quad 783$

Road Motor Vehicles, N.E.S. $\quad 55.27$

$91.90791 \quad$ Railway Vehicles

51.52

$79.58 \quad 793$

Ships, Boats And Floating

Structures

$88.83 \quad 894$

Baby Carriages, Toys, Games And Sporting Goods

Musical Instruments

Miscellaneous Manufactured Articles, N.E.S.

Source United Nations Comtrade Database, 2015, Author's calculations.

B8. ASEAN-New Zealand Intra Industry Trade by Industry: 3-digit SITC (High Category) in 2014

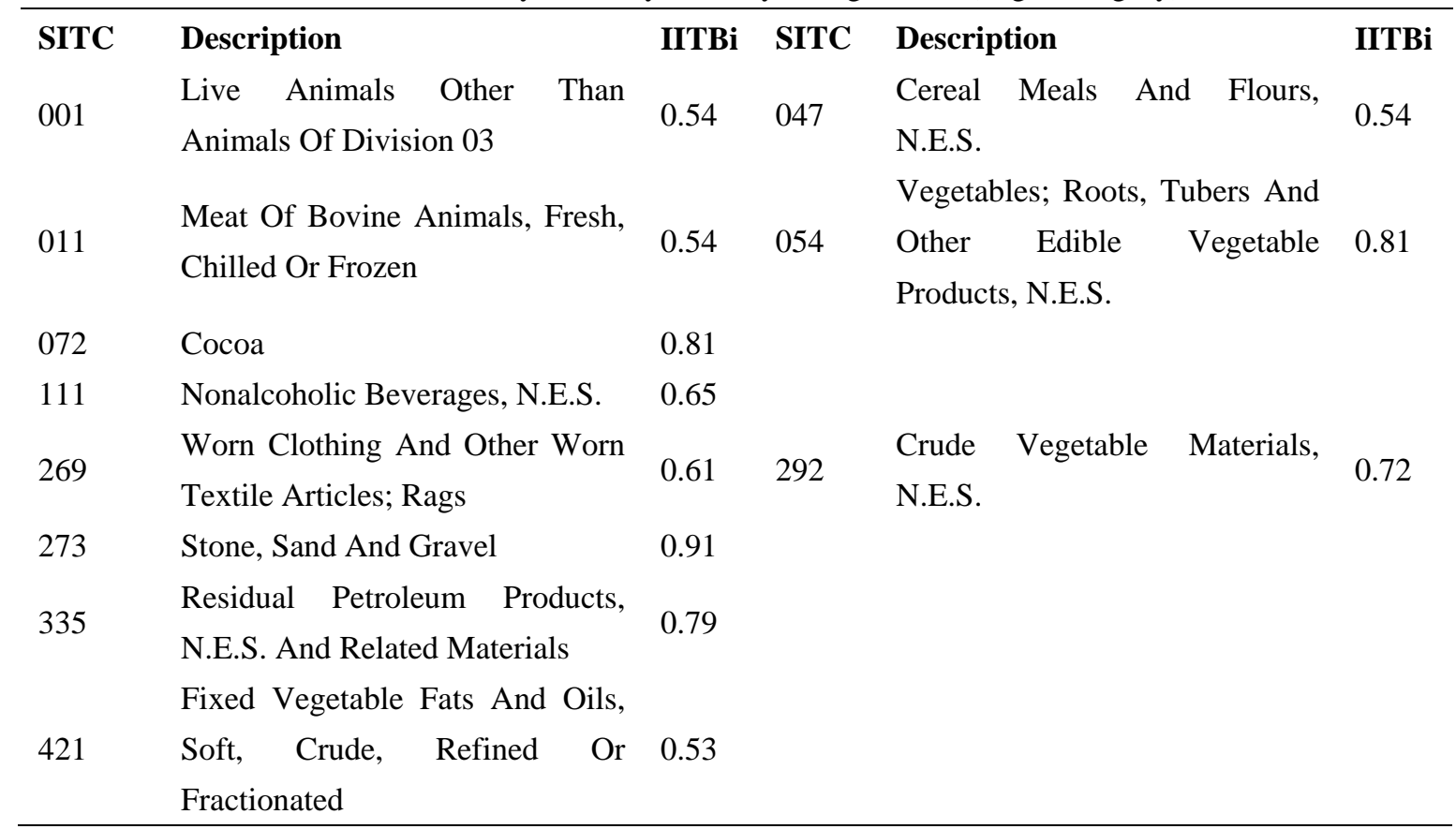




\begin{tabular}{|c|c|c|c|c|c|}
\hline 533 & $\begin{array}{l}\text { Pigments, Paints, Varnishes And } \\
\text { Related Materials }\end{array}$ & 0.86 & 598 & $\begin{array}{l}\text { Miscellaneous } \quad \text { Chemical } \\
\text { Products, N.E.S. }\end{array}$ & 0.98 \\
\hline 581 & $\begin{array}{l}\text { Tubes, Pipes And Hoses Of } \\
\text { Plastics }\end{array}$ & 0.96 & & & \\
\hline 621 & $\begin{array}{l}\text { Materials Of Rubber, Including } \\
\text { Pastes, Plates, Sheets, Rods, } \\
\text { Thread, Tubes, Etc. }\end{array}$ & 0.57 & 679 & $\begin{array}{l}\text { Iron And Steel Tubes, Pipes } \\
\text { And Hollow Profiles, Fittings } \\
\text { For Tubes And Pipes }\end{array}$ & 0.76 \\
\hline 629 & Articles Of Rubber, N.E.S. & 0.70 & 681 & $\begin{array}{l}\text { Silver, Platinum And Other } \\
\text { Platinum Group Metals }\end{array}$ & 0.51 \\
\hline 635 & Wood Manufactures, N.E.S. & 0.92 & 684 & Aluminum & 0.95 \\
\hline 661 & $\begin{array}{l}\text { Lime, Cement, And Fabricated } \\
\text { Construction Materials, Except } \\
\text { Glass And Clay Materials }\end{array}$ & 0.73 & 691 & $\begin{array}{l}\text { Metal Structures And Parts, } \\
\text { N.E.S., Of Iron, Steel Or } \\
\text { Aluminum }\end{array}$ & 0.59 \\
\hline 673 & $\begin{array}{l}\text { Iron Or Nonalloy Steel } \\
\text { Flat-Rolled Products, Not Clad, } \\
\text { Plated Or Coated }\end{array}$ & 0.82 & 694 & $\begin{array}{l}\text { Nails, Screws, Nuts, Bolts, } \\
\text { Rivets And Similar Articles, Of } \\
\text { Iron, Steel, Copper Or } \\
\text { Aluminum }\end{array}$ & 0.91 \\
\hline 674 & $\begin{array}{l}\text { Iron And Nonalloy } \\
\text { Flat-Rolled Products, } \\
\text { Clad, } \\
\text { Plated Or Coated }\end{array}$ & 0.75 & 699 & $\begin{array}{l}\text { Manufactures Of Base Metal, } \\
\text { N.E.S. }\end{array}$ & 0.95 \\
\hline 714 & Engines And Motors, Nonelectric & 0.65 & 745 & $\begin{array}{l}\text { Nonelectrical Machinery, Tools } \\
\text { And Mechanical Apparatus }\end{array}$ & 0.54 \\
\hline 718 & $\begin{array}{l}\text { Power Generating Machinery } \\
\text { And Parts Thereof, N.E.S. }\end{array}$ & 0.53 & 747 & $\begin{array}{l}\text { Taps, Cocks, Valves And } \\
\text { Similar Appliances For Pipes }\end{array}$ & 0.77 \\
\hline 723 & $\begin{array}{lrr}\text { Civil } \quad \text { Engineering } & \text { And } \\
\text { Contractors' } & \text { Plant } & \text { And } \\
\text { Equipment } & & \end{array}$ & 0.88 & 748 & $\begin{array}{l}\text { Transmission } \quad \text { Shafts } \quad \text { And } \\
\text { Cranks }\end{array}$ & 0.55 \\
\hline 724 & $\begin{array}{l}\text { Textile And Leather Machinery, } \\
\text { And Parts Thereof, N.E.S. }\end{array}$ & 0.70 & 764 & $\begin{array}{l}\text { Telecommunications } \\
\text { Equipment }\end{array}$ & 0.72 \\
\hline 726 & $\begin{array}{l}\text { Printing And Bookbinding } \\
\text { Machinery, And Parts Thereof }\end{array}$ & 0.70 & 771 & Electric Power Machinery & 0.75 \\
\hline 727 & $\begin{array}{ll}\text { Food-Processing } & \text { Machines } \\
\text { (Excluding Domestic) } & \end{array}$ & 0.58 & 772 & $\begin{array}{l}\text { Electrical Apparatus For } \\
\text { Switching Or Protecting } \\
\text { Electrical Circuits }\end{array}$ & 0.95 \\
\hline 728 & $\begin{array}{lrr}\text { Machinery } & \text { And } & \text { Equipment } \\
\text { Specialized } & \text { For } & \text { Particular } \\
\text { Industries } & & \end{array}$ & 0.56 & 776 & $\begin{array}{l}\text { Thermionic, Cold Cathode Or } \\
\text { Photocathode Valve }\end{array}$ & 0.55 \\
\hline 731 & $\begin{array}{l}\text { Machine Tools Working By } \\
\text { Removing Metal Or Other } \\
\text { Material }\end{array}$ & 0.56 & 793 & $\begin{array}{l}\text { Ships, Boats And Floating } \\
\text { Structures }\end{array}$ & 0.92 \\
\hline 813 & $\begin{array}{l}\text { Lighting Fixtures And Fittings, } \\
\text { N.E.S. }\end{array}$ & 0.87 & 872 & Instruments And Appliances & 0.99 \\
\hline
\end{tabular}




\begin{tabular}{|c|c|c|c|c|c|c|}
\hline & $\begin{array}{l}\text { lacrothink } \\
\text { nstitute }{ }^{T M}\end{array}$ & Inter & lational & Journal & of Accounting and & $\begin{array}{r}\text { Financial Reporting } \\
\text { ISSN 2162-3082 } \\
\text { 2018, Vol. 8, No. } 4\end{array}$ \\
\hline 871 & $\begin{array}{l}\text { Optical Instruments } \\
\text { Apparatus, N.E.S. }\end{array}$ & And & 1.00 & 892 & Printed Matter & 0.56 \\
\hline 971 & Gold, Nonmonetary & & 0.43 & & & \\
\hline
\end{tabular}

Source: United Nations Comtrade Database, 2015. Author's calculations.

B9. Determinants of IIT between ASEAN and Australia: 1990-2013

\begin{tabular}{llllllll}
\hline Year & IITB & IITC & IITQ & ALD & AMS & LDD & MSD \\
1990 & 38.6 & 42.6 & 40.7 & 9.5 & 324.0 & 26.1 & 17.3 \\
1991 & 41.8 & 45.6 & 43.6 & 9.9 & 352.7 & 54.1 & 17.9 \\
1992 & 39.7 & 41.1 & 42.3 & 9.8 & 377.1 & 103.6 & 17.5 \\
1993 & 41.1 & 43.7 & 41.5 & 9.4 & 397.1 & 170.2 & 16.5 \\
1994 & 40.4 & 40.9 & 43.3 & 9.7 & 438.4 & 231.0 & 16.7 \\
1995 & 40.5 & 41.2 & 43.2 & 11.0 & 507.2 & 278.4 & 18.8 \\
1996 & 46.3 & 50.6 & 49.6 & 11.8 & 560.3 & 317.8 & 20.2 \\
1997 & 41.5 & 44.8 & 44.7 & 12.5 & 558.5 & 245.7 & 22.0 \\
1998 & 37.1 & 51.3 & 44.6 & 11.2 & 434.0 & 69.3 & 20.3 \\
1999 & 34.0 & 51.8 & 45.6 & 10.9 & 466.5 & 155.7 & 19.3 \\
2000 & 40.0 & 58.0 & 53.2 & 11.5 & 506.5 & 183.1 & 20.4 \\
2001 & 42.5 & 57.1 & 54.3 & 10.4 & 476.8 & 196.7 & 18.2 \\
2002 & 38.4 & 58.5 & 54.7 & 10.7 & 517.4 & 246.2 & 18.7 \\
2003 & 37.1 & 61.8 & 51.9 & 12.5 & 592.1 & 251.3 & 21.9 \\
2004 & 31.5 & 56.6 & 52.6 & 16.1 & 709.3 & 192.9 & 28.8 \\
2005 & 34.6 & 58.2 & 53.2 & 17.9 & 798.4 & 210.1 & 32.1 \\
2006 & 35.3 & 60.0 & 55.9 & 19.1 & 914.7 & 335.0 & 33.9 \\
2007 & 33.6 & 59.9 & 55.1 & 21.8 & $1,072.6$ & 438.3 & 38.4 \\
2008 & 36.1 & 62.0 & 54.1 & 26.3 & $1,274.1$ & 438.1 & 46.7 \\
2009 & 35.9 & 64.2 & 53.4 & 22.8 & $1,204.7$ & 556.7 & 39.8 \\
2010 & 35.1 & 62.4 & 52.1 & 27.7 & $1,490.6$ & 698.7 & 48.3 \\
2011 & 32.7 & 52.1 & 49.9 & 33.1 & $1,759.8$ & 743.5 & 58.1 \\
2012 & 32.6 & 59.2 & 52.7 & 35.9 & $1,896.1$ & 723.4 & 63.3 \\
2013 & 28.1 & 51.5 & 51.7 & 35.9 & $1,943.3$ & 765.9 & 63.2 \\
\hline & & & & & & & \\
\hline
\end{tabular}

Source: UN Comtrade Database; World Development Indicators, the World Bank, 2015, Author's calculation.

Note: IITB: Grubel-Lloyd IIT index

IITC: Grubel-Lloyd Trade imbalance Adjusted IIT index

IITQ: Aquino; Trade imbalance Adjusted IIT index

ALD (Average Level of Development) and LDD (Level of Development Differential) are measured in US\$ thousands;

AMS (Average Market Size) and MSD (Market Size Difference) are measured inUS\$ millions. 


\section{Macrothink}

International Journal of Accounting and Financial Reporting ISSN 2162-3082

Note

Note 1. The countries listed in the Organization for Economic Co-operation and Development.

\section{Copyright Disclaimer}

Copyright for this article is retained by the author(s), with first publication rights granted to the journal.

This is an open-access article distributed under the terms and conditions of the Creative Commons Attribution license (http://creativecommons.org/licenses/by/4.0/) 